
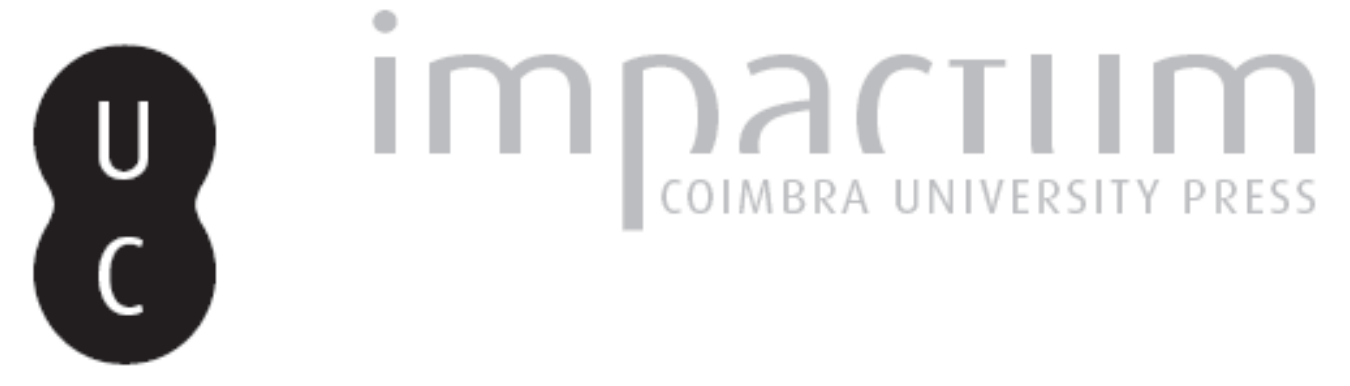

\title{
Poluição marinha, hidrocarbonetos e resíduos: o caso do Erika no TJCE
}

Autor(es): Coelho, Carlos Oliveira

Publicado por: CEDOUA

URL persistente:

URI:http://hdl.handle.net/10316.2/37563

DOI:

DOI:http://dx.doi.org/10.14195/2182-2387_24_5

Accessed : $\quad$ 26-Apr-2023 16:21:31

A navegação consulta e descarregamento dos títulos inseridos nas Bibliotecas Digitais UC Digitalis, UC Pombalina e UC Impactum, pressupõem a aceitação plena e sem reservas dos Termos e Condições de Uso destas Bibliotecas Digitais, disponíveis em https://digitalis.uc.pt/pt-pt/termos.

Conforme exposto nos referidos Termos e Condições de Uso, o descarregamento de títulos de acesso restrito requer uma licença válida de autorização devendo o utilizador aceder ao(s) documento(s) a partir de um endereço de IP da instituição detentora da supramencionada licença.

Ao utilizador é apenas permitido o descarregamento para uso pessoal, pelo que o emprego do(s) título(s) descarregado(s) para outro fim, designadamente comercial, carece de autorização do respetivo autor ou editor da obra.

Na medida em que todas as obras da UC Digitalis se encontram protegidas pelo Código do Direito de Autor e Direitos Conexos e demais legislação aplicável, toda a cópia, parcial ou total, deste documento, nos casos em que é legalmente admitida, deverá conter ou fazer-se acompanhar por este aviso.

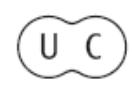




\section{RevGEDOUA}

N.224_Ano XII_ 2.09

> Doutrina

Gestāo Integrada da Zona Costeira Portuguesa

Fernanda do Carmo

E um dia a Falésia veio Abaixo. Pisco de Erosāo da Orla Costeira, Prevenção e Hesponsabilizaçāo

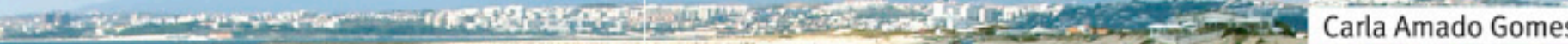

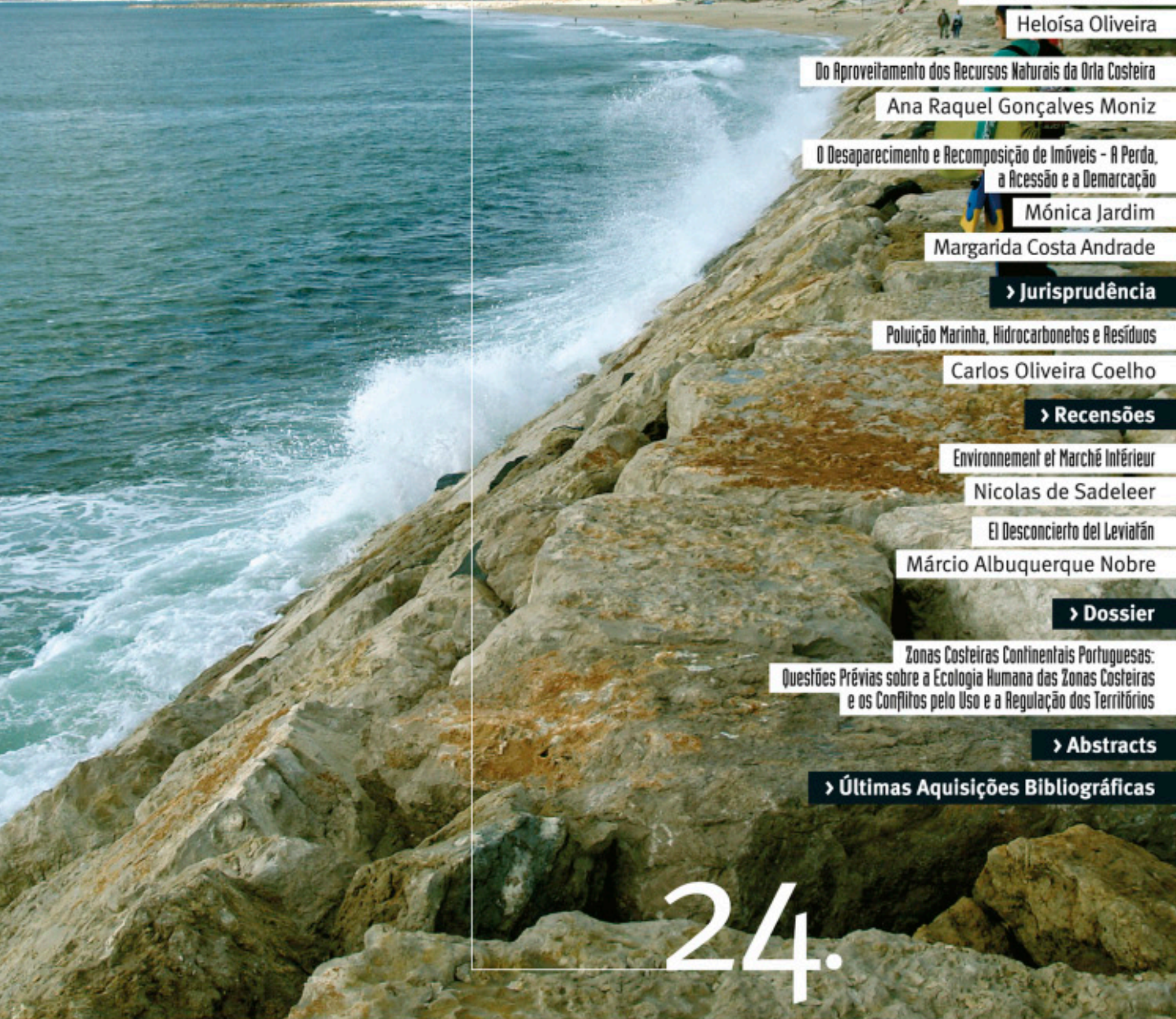




\section{Poluição marinha, hidrocarbonetos e resíduos (O caso do Erika no TJCE)}

\section{ACÓRDÃO DO TRIBUNAL DE JUSTIÇA (Grande Secção)}

24 de Junho de $2008\left(^{\star}\right)$

«Directiva 75/442/CEE - Gestão dos resíduos - Conceito de resíduos - Princípio do poluidor pagador - Detentor - Detentores anteriores - Produtor do produto gerador - Hidrocarbonetos e fuelóleo pesado - Naufrágio - Convenção sobre responsabilidade civil pelos prejuízos devidos à poluição por hidrocarbonetos - FIPOL»

No processo C $188 / 07$,

que tem por objecto um pedido de decisão prejudicial nos termos do artigo $234 .^{\circ} \mathrm{CE}$, apresentado pela Cour de cassation (França), por acórdão de 28 de Março de 2007, entrado no Tribunal de Justiça em 3 de Abril de 2007, no processo

\section{Commune de Mesquer}

contra

\section{Total France SA,}

\section{Total International Ltd,}

O TRIBUNAL DE JUSTIÇA (Grande Secção),

composto por: C. W. A. Timmermans, presidente da Segunda Secção, exercendo funções de presidente, A. Rosas, K. Lenaerts e L. Bay Larsen, presidentes de secção, R. Silva de Lapuerta, K. Schiemann, P. Kuris, E. Levits, A. Ó Caoimh, P. Lindh, J. C. Bonichot, T. von Danwitz e C. Toader (relator), juízes,

advogada geral: J. Kokott,

secretário: M. A. Gaudissart, chefe de unidade,

vistos os autos e após a audiência de 22 de Janeiro de 2008 ,

vistas as observações apresentadas:

- em representação da commune de Mesquer, por C. Lepage e A. Moustardier, avocats,

- em representação da Total France SA e da Total International Ltd, por J. P. Hordies, C. Smits, M. Memlouk, J. Boivin, E. Fontaine e F. H. Briard, avocats,

- em representação do Governo francês, por G. de Bergues e A. L. During, na qualidade de agentes,

- em representação do Governo belga, por L. Van den Broeck, na qualidade de agente, 
- em representação do Governo italiano, por I. M. Braguglia, na qualidade de agente, assistido por M. Del Gaizo, avvocato dello Stato,

- em representação do Governo do Reino Unido, por C. Gibbs e I. Rao, na qualidade de agentes, assistidas por J. Maurici, barrister,

- em representação da Comissão das Comunidades Europeias, por M. Konstantinidis, J. B. Laignelot e G. Valero Jordana, na qualidade de agentes,

ouvidas as conclusões da advogada geral na audiência de 13 de Março de 2008,

profere o presente

\section{Acórdão}

10 pedido de decisão prejudicial tem por objecto a interpretação dos artigos $1 .^{\circ}$ e $15 .^{\circ}$ da Directiva 75/442/CEE do Conselho, de 15 de Julho de 1975, relativa aos resíduos (JO L 194, p. 39; EE 15 F1 p. 129), alterada pela Decisão 96/350/CE da Comissão, de 24 de Maio de 1996 (JO L 135, p. 32, a seguir «Directiva 75/442»), e do anexo I dessa directiva.

20 pedido foi apresentado no quadro de um litígio que opõe a commune de Mesquer à Total France SA e à Total International Ltd (a seguir, conjuntamente, «sociedades Total»), a propósito do ressarcimento dos danos causados pelos resíduos derramados no território da referida commune (a seguir «autarquia»), na sequência do naufrágio do petroleiro Erika.

\section{Quadro jurídico}

\section{Regulamentação internacional}

3 A Convenção Internacional sobre responsabilidade civil pelos prejuízos devidos à poluição por hidrocarbonetos, adoptada em Bruxelas, em 29 de Novembro de 1969, alterada pelo protocolo assinado em Londres, em 27 de Novembro de 1992 (JO 2004, L 78, p. 32, a seguir «convenção sobre responsabilidade civil»), regula a responsabilidade dos proprietários de navios pelos danos resultantes do derrame de hidrocarbonetos persistentes provenientes de navios tanque. Consagra 0 princípio da responsabilidade objectiva dos referidos proprietários, limitada a um montante calculado em função da arqueação do navio, e institui um sistema de seguro de responsabilidade obrigatório.

4 Nos termos do artigo II, alínea a), da convenção sobre responsabilidade civil, esta aplica-se aos prejuízos devidos à poluição causados no território, incluindo o mar territorial, de um Estado contratante e na zona económica exclusiva desse Estado, estabelecida em conformidade com o direito internacional ou, eventualmente, numa área para além e adjacente ao mar territorial desse Estado, determinada por esse Estado em conformidade com o direito internacional, numa extensão não superior a 200 milhas náuticas contadas a partir das linhas de base utilizadas para determinar a largura do mar territorial.

5 Nos termos do artigo III, n. ${ }^{4}$, da convenção sobre responsabilidade civil, «[n]enhum pedido de reparação por prejuízos devidos à poluição, que não tenha por fundamento o disposto na presente convenção, pode ser formulado contra [...] [q]ualquer afretador (seja qual for o seu estatuto, incluindo o afretador de navio em casco nu), gestor ou operador do navio [...] excepto se o prejuízo resultar de acção ou omissão destas pessoas com a intenção de causar tal prejuízo ou por imprudência e com o conhecimento de que tal prejuízo poderia vir a ocorrer».

6 A Convenção Internacional para a constituição de um fundo internacional para compensação pelos prejuízos devidos à poluição por hidrocarbonetos, adoptada em Bruxelas, em 18 de Dezembro de 1971, alterada pelo Protocolo assinado em Londres, em 27 de Novembro de 1992 (JO 2004, L 78, 


\section{RerCED光UA \\ > Jurisprudência}

p. 40, a seguir «convenção FIPOL»), completa a convenção sobre responsabilidade civil, instituindo um regime de indemnização das vítimas.

70 Fundo Internacional para compensação pelos prejuízos devidos à poluição por hidrocarbonetos (a seguir «FIPOL»), alimentado por contribuições da indústria petrolífera, pode cobrir até 135 milhões de DTS (direitos de saque especiais) relativamente a qualquer acontecimento anterior a 2003. Nos termos do artigo $4 .^{\circ}$ da convenção FIPOL, as vítimas podem pedir uma indemnização, nos tribunais do Estado parte nessa convenção, onde os prejuízos ocorreram, designadamente quando a convenção sobre responsabilidade civil não preveja nenhuma responsabilidade pelo dano em questão ou quando o proprietário do navio seja insolvente ou não seja responsável por força da referida convenção.

80 Protocolo de 2003 à Convenção Internacional para a constituição de um fundo para compensação pelos prejuízos devidos à poluição por hidrocarbonetos, de 1992 (JO 2004, L 78, p. 24), institui um fundo complementar internacional para compensação pelos prejuízos devidos à poluição por hidrocarbonetos, designado «Fundo internacional complementar para compensação pelos prejuízos devidos à poluição por hidrocarbonetos, 2003", que permite, em conjunto com o FIPOL, cobrir até 750 milhões de unidades de conta os prejuízos ocorridos depois de 1 de Novembro de 2003.

\section{Regulamentação comunitária}

\section{Directiva $75 / 442 /$ CEE}

9 Nos termos do terceiro considerando da Directiva 75/442, qualquer regulamentação em matéria de eliminação dos resíduos deve ter como objectivo essencial a protecção da saúde humana e do ambiente contra os efeitos nocivos da recolha, do transporte, do tratamento, do armazenamento e do depósito dos resíduos.

100 artigo $1 .^{\circ}$ da Directiva $75 / 442$ estabelece:

«Para efeitos do disposto na presente directiva, entende se por:

a) Resíduo: quaisquer substâncias ou objectos abrangidos pelas categorias fixadas no anexo I, de que o detentor se desfaz ou tem a intenção ou a obrigação de se desfazer.

A Comissão [...] elaborará [...] uma lista dos resíduos pertencentes às categorias constantes do anexo I. [...];

b) Produtor: qualquer pessoa cuja actividade produza resíduos (produtor inicial) e/ou qualquer pessoa que efectue operações de pré tratamento, de mistura ou outras, que conduzam a uma alteração da natureza ou da composição desses resíduos;

c) Detentor: o produtor dos resíduos ou a pessoa singular ou colectiva que tem os resíduos na sua posse;

$[\ldots]$

e) Eliminação: qualquer das operações previstas no anexo II A;

f) Aproveitamento: qualquer das operações previstas no anexo II B;

g) Recolha: a operação de apanha, triagem e/ou mistura de resíduos com vista ao seu transporte.»

110 artigo $8 .^{\circ}$ da Directiva $75 / 442$ dispõe: 


\section{RerCEDöUA}

> Jurisprudência

«Os Estados Membros tomarão as disposições necessárias para que qualquer detentor de resíduos:

- confie a sua manipulação a um serviço de recolha privado ou público ou a uma empresa que efectue as operações referidas no anexo II A ou II B

ou

- proceda ele próprio ao respectivo aproveitamento ou eliminação, em conformidade com o disposto na presente directiva.»

12 As categorias Q4, Q11, Q13 e Q16 do anexo I da Directiva 75/442, intitulado «Categorias de resíduos», encontram se definidas nos seguintes termos:

«Q4 Matérias acidentalmente derramadas, perdidas ou que sofreram qualquer outro incidente, incluindo quaisquer matérias, equipamentos, etc., contaminados na sequência do incidente em causa

$[\ldots]$

Q11 Resíduos de extracção e de preparação de matérias primas (por exemplo, resíduos de exploração mineira ou petrolífera, etc.)

\section{$[\ldots]$}

Q13 Qualquer matéria, substância ou produto cuja utilização seja proibida por lei

\section{$[\ldots]$}

Q16 Qualquer substância, matéria ou produto que não esteja abrangido pelas categorias acima referidas.»

130 anexo II A desta directiva, intitulado «Operações de eliminação», destina se a enumerar as operações de eliminação tal como são efectuadas na prática, enquanto o seu anexo II B, intitulado «Operações de valorização», destina se a, da mesma forma, enumerar as operações de valorização.

140 artigo $15 .^{\circ}$ da Directiva $75 / 442$ prevê:

«Em conformidade com o princípio do 'poluidor pagador', os custos da eliminação dos resíduos devem ser suportados:

- pelo detentor que entrega os resíduos a um serviço de recolha ou a uma das empresas mencionadas no artigo $9 .^{\circ}$

e/ou

- pelos detentores anteriores ou pelo produtor do produto gerador dos resíduos.»

15 A Directiva 2006/12/CE do Parlamento Europeu e do Conselho, de 5 de Abril de 2006, relativa aos resíduos (JO L 114, p. 9), que, por uma questão de lógica e clareza, procede à codificação da Directiva 75/442, reproduz, nos seus artigos $1 .^{\circ}$ e $15 .^{\circ}$ e nos seus anexos I, II A e II B, as mencionadas disposições. Contudo, a Directiva 2006/12 só foi adoptada posteriormente à ocorrência dos factos do processo principal, pelo que não se aplica ao litígio no processo principal.

\section{Directiva 68/414/CEE}

160 artigo $2 .^{\circ}$ da Directiva 68/414/CEE do Conselho, de 20 de Dezembro de 1968, que obriga 
os Estados Membros da CEE a manterem um nível mínimo de existências de petróleo bruto e/ou de produtos petrolíferos (JO L 308, p. 14; EE 12 F1 p. 125), alterada pela Directiva 98/93/CE do Conselho, de 14 de Dezembro de 1998 (JO L 358, p. 100), que prevê essa mesma obrigação para, designadamente, se fazer face a eventuais penúrias ou crises de abastecimento, equipara os fuelóleos a uma categoria de produtos petrolíferos.

\section{Directiva 2004/35/CE}

17 O décimo considerando da Directiva 2004/35/CE do Parlamento Europeu e do Conselho, de 21 de Abril de 2004, relativa à responsabilidade ambiental em termos de prevenção e reparação de danos ambientais (JO L 143, p. 56), está redigido nos seguintes termos:

«Devem ser expressamente tidos em conta o Tratado Euratom, as convenções internacionais aplicáveis e a legislação comunitária que regulem de forma mais abrangente e rigorosa o exercício de quaisquer actividades incluídas no âmbito da presente directiva. [...]»

180 artigo $4 .^{\circ}$, n. ${ }^{\circ}$ 2, da Directiva 2004/35 estabelece:

«A presente directiva não se aplica aos danos ambientais, nem a ameaças iminentes desses danos, que resultem de incidentes relativamente aos quais a responsabilidade ou compensação seja abrangida pelo âmbito de aplicação de alguma das convenções internacionais enumeradas no anexo IV, incluindo quaisquer posteriores alterações dessas convenções, em vigor no Estado Membro em questão.»

19 O anexo IV da Directiva 2004/35 está redigido nos seguintes termos:

«Convenções internacionais referidas no n. ${ }^{\circ} 2$ do artigo $4 .^{\circ}$

a) Convenção Internacional de 27 de Novembro de 1992 sobre a responsabilidade civil pelos prejuízos devidos à poluição por hidrocarbonetos;

b) Convenção Internacional de 27 de Novembro de 1992 para a constituição de um fundo internacional para compensação pelos prejuízos devidos à poluição por hidrocarbonetos;

$[\ldots] »$

Decisão 2004/246/CE

20 O Conselho adoptou, em 2 de Março de 2004, a Decisão 2004/246/CE que autoriza os Estados Membros a assinar ou a ratificar, no interesse da Comunidade Europeia, [o] Protocolo de 2003 à Convenção Internacional para a constituição de um fundo internacional para compensação pelos prejuízos devidos à poluição por hidrocarbonetos, de 1992, e que autoriza a Áustria e o Luxemburgo a aderirem, no interesse da Comunidade Europeia, aos instrumentos de referência $(J O L$ 78, p. 22).

210 quarto considerando da Decisão 2004/246 está redigido nos seguintes termos:

«Nos termos do protocolo do fundo complementar, apenas Estados soberanos podem ser parte no protocolo; não é, por conseguinte, possível a Comunidade ratificar ou aderir ao protocolo, nem se prevê que o possa fazer num futuro próximo.»

22 Os artigos $1 .^{\circ}, \mathrm{n} .^{\circ} 1$, e $4 .^{\circ}$ da Decisão $2004 / 246$ estão redigidos nos seguintes termos:

«Artigo $1 .^{\circ}$

1. Os Estados Membros são autorizados a assinar ou a ratificar, no interesse da Comunidade Europeia, [o] protocolo de 2003 à Convenção Internacional para a constituição de um fundo internacional para compensação pelos prejuízos devidos à poluição por hidrocarbonetos, de 1992 (a seguir designado por 'protocolo do fundo complementar'), nas condições estabelecidas nos artigos seguintes. 
$[\ldots]$

Artigo $4 .^{\circ}$

Os Estados-Membros farão, no mais breve prazo, tudo o que estiver ao seu alcance para garantir que o protocolo do fundo complementar, e os instrumentos de referência, sejam alterados de forma a permitir que a Comunidade se torne parte contratante neles.»

\section{Legislação nacional}

230 artigo $2 .^{\circ}$ da Lei n. ${ }^{\circ} 75-633$, de 15 de Julho de 1975 , relativa à eliminação dos resíduos e à recuperação dos materiais (loi relative à l'élimination des déchets et à la récupération des matériaux, JORF de 16 de Julho de 1975, p. 7279), actualmente artigo L. 5412 do Código do Ambiente (code de l'environnement), estabelece:

«Qualquer pessoa que produza ou detenha resíduos em condições passíveis de produzir efeitos nocivos no solo, na flora e na fauna, de degradar os locais ou as paisagens, de poluir o ar ou as águas, de gerar ruídos e odores e, de uma forma geral, de prejudicar a saúde humana e o ambiente é obrigada a assegurar ou a fazer assegurar a respectiva eliminação, em conformidade com as disposições constantes do presente capítulo, nas condições adequadas a evitar os referidos efeitos.

A eliminação dos resíduos inclui as operações de recolha, transporte, armazenagem, triagem e tratamento, necessárias à recuperação dos elementos e materiais reutilizáveis ou da energia, bem como ao depósito ou à rejeição, no meio natural, de todos os outros produtos, em condições adequadas a evitar os danos ambientais mencionados na alínea anterior.»

\section{Litígio no processo principal e questões prejudiciais}

24 Em 12 de Dezembro de 1999, o petroleiro Erika, que arvorava pavilhão maltês e afretado pela Total International Ltd, naufragou a cerca de 35 milhas náuticas, a sudoeste do cabo de Penmarc’h (Finistère, França), derramando uma parte da sua carga e do seu combustível no mar e poluindo o litoral atlântico francês.

25 Do acórdão de reenvio e das observações apresentadas a este tribunal resulta que a sociedade italiana ENEL celebrou com a Total International Ltd um contrato de fornecimento de fuelóleo pesado para ser utilizado como combustível na produção de electricidade. Para cumprimento desse contrato, a Total raffinage distribution, actualmente Total France, vendeu esse fuelóleo pesado à sociedade Total international Ltd, que afretou o navio Erika para o transportar do porto de Dunkerque (França) para o porto de Millazo (Itália).

26 Foi contra as sociedades Total que a autarquia de Mesquer intentou no tribunal de commerce de Saint Nazaire, em 9 de Junho de 2000, uma acção para, nomeadamente, obter a declaração de que essas sociedades deviam, por força do disposto na Lei n. ${ }^{\circ} 75$ 633, assumir as consequências dos danos causados pelos resíduos derramados no seu território e ser condenadas in solidum no pagamento das despesas que a autarquia teve de suportar com as operações de limpeza e de despoluição, ou seja, 69 232,42 euros.

27 Tendo a sua aç̧ão sido julgada improcedente, a autarquia de Mesquer interpôs recurso para a cour d'appel de Rennes, que, por acórdão de 13 de Fevereiro de 2002, confirmou a decisão de primeira instância, declarando que o fuelóleo pesado, no caso concreto, não era um resíduo mas sim uma matéria combustível que constitui uma matéria energética elaborada para uma determinada utilização. Na verdade, a cour d'appel de Rennes reconheceu que o fuelóleo pesado, derramado e transformado ao misturar se com a água e a areia, gerou resíduos, mas entendeu que nenhuma disposição permitia imputar responsabilidades às sociedades Total, porquanto não podiam ser consideradas produtoras ou detentoras dos referidos resíduos. A autarquia de Mesquer interpôs então recurso de cassação. 
28 Por considerar que o litígio suscita uma dificuldade séria de interpretação da Directiva 75/442, a Cour de cassation decidiu suspender a instância e submeter ao Tribunal de Justiça as seguintes questões prejudiciais:

«1) O fuelóleo pesado, produto resultante de um processo de refinação, de acordo com as especificações do utilizador, destinado pelo produtor a ser vendido como combustível e mencionado na Directiva 68/414 [...] pode ser qualificado de resíduo, na acepção do artigo $1.0^{\circ}$ da Directiva 75/442 [...] codificada pela Directiva 2006/12 [...]?

2) Uma carga de fuelóleo pesado, transportada por um navio e acidentalmente derramada no mar, constitui, em si mesma ou em virtude da sua mistura com água e sedimentos, um resíduo na acepção [da categoria] Q4 do anexo I da Directiva 2006/12 [...]?

3) Em caso de resposta negativa à primeira questão e positiva à segunda, o produtor do fuelóleo pesado (Total raffinage [distribution]) e/ou o vendedor e afretador (Total international Ltd) podem ser considerados, na acepção do artigo $1 .^{\circ}$, alíneas b) e c), da Directiva 2006/12 [...] e para efeitos da aplicação do artigo $15 .^{\circ}$ da mesma directiva, produtores e/ou detentores do resíduo, apesar de, no momento do acidente que o transformou em resíduo, o produto ser transportado por um terceiro?»

\section{Quanto às questões prejudiciais}

\section{Quanto à admissibilidade}

29 As sociedades Total sustentam que o presente reenvio prejudicial deve ser julgado inadmissível, porquanto a autarquia de Mesquer já foi indemnizada ao abrigo do FIPOL e, por conseguinte, não tem interesse em demandar. Nestas condições, o pedido de decisão prejudicial tem carácter hipotético.

30 Segundo jurisprudência assente, as questões relativas à interpretação do direito comunitário colocadas pelo juiz nacional no quadro factual e regulamentar definidos sob sua responsabilidade, e cuja exactidão não compete ao Tribunal de Justiça verificar, gozam de presunção de pertinência. 0 Tribunal de Justiça só pode recusar se a responder a uma questão submetida à sua apreciação por um órgão jurisdicional nacional, quando for manifesto que a interpretação do direito comunitário solicitada não tem nenhuma relação com a realidade ou com o objecto do litígio no processo principal, quando o problema for hipotético ou ainda quando o Tribunal de Justiça não disponha dos elementos de facto e de direito necessários para dar uma resposta útil às questões que the foram submetidas (v., neste sentido, acórdão de 7 de Junho de 2007, van der Weerd e 0., C-222/05 a C- 225/05, Colect., p. I-4233, n. ${ }^{\circ} 22$ e jurisprudência aí indicada).

31 Além disso, em conformidade com jurisprudência assente, compete aos órgãos jurisdicionais nacionais a quem sejam submetidos os litígios apreciar tanto a necessidade de uma decisão prejudicial, para estarem em condições de proferir a sua decisão, como a pertinência das questões que colocam ao Tribunal de Justiça (acórdão de 15 de Junho de 2006, Air Liquide Industries Belgium, C- 393/04 e C-41/05, Colect., p. I-5293, n. ${ }^{\circ} 24$ e jurisprudência aí indicada).

32 A este propósito, resulta dos autos que a autarquia de Mesquer beneficiou efectivamente de montantes que lhe foram pagos ao abrigo do FIPOL, na sequência do pedido de indemnização que tinha apresentado, nomeadamente, ao proprietário do navio Erika e ao FIPOL. Estes pagamentos resultaram de um acordo nos termos do qual a referida autarquia renunciou expressamente ao recurso às vias judiciais, sob pena de ter de devolver todos os montantes pagos.

330 órgão jurisdicional de reenvio dispunha destas informações, mas, contudo, não considerou que o litígio no processo principal tivesse terminado ou que a autarquia de Mesquer tivesse perdido o seu interesse em demandar, e submeteu as questões prejudiciais ao Tribunal de Justiça.

34 Nestas condições, há que responder às questões colocadas pela Cour de cassation. 


\section{$\operatorname{RerCEDळ̈UA~}$ \\ > Jurisprudência}

\section{Quanto à primeira questão}

35 Através da primeira questão, o órgão jurisdicional de reenvio pretende saber se o fuelóleo vendido como combustível pode ser considerado resíduo na acepção do artigo $1 .^{\circ}$, alínea a), da Directiva $75 / 442$.

36 As sociedades Total, os Estados Membros que apresentaram observações e a Comissão entendem que se deve responder pela negativa a esta questão. Só a autarquia de Mesquer é que defende que esse fuelóleo pesado deve ser qualificado de resíduo e, além disso, que a substância em causa faz parte da categoria dos produtos perigosos e ilícitos.

37 A título preliminar, importa recordar que, nos termos do artigo 1. ${ }^{\circ}$, alínea a), da Directiva 75/442, considera se resíduo quaisquer substâncias ou objectos abrangidos pelas categorias fixadas no anexo I dessa directiva, de que o detentor se desfaz ou tem a intenção ou a obrigação de se desfazer.

38 Assim, no contexto da referida directiva, o campo de aplicação do conceito de resíduo depende do significado da expressão «se desfazer» (acórdão de 18 de Dezembro de 1997, Inter Environnement Wallonie, C-129/96, Colect., p. I-7411, n. ${ }^{\circ}$ 26) e, por conseguinte, em conformidade com a jurisprudência do Tribunal de Justiça, essa expressão deve ser interpretada à luz do objectivo dessa mesma directiva (acórdão de 15 de Junho de 2000, ARCO Chemie Nederland e 0., C 418/97 e C 419/97, Colect., p. I 4475, n. ${ }^{\circ}$ 37), que, nos termos do terceiro considerando da referida directiva, consiste na protecção da saúde humana e do ambiente contra os efeitos nocivos da recolha, do transporte, do tratamento, do armazenamento e do depósito dos resíduos, bem como à luz do artigo $174 .^{\circ}, \mathrm{n}^{\circ} 2$, CE, que estipula que a política da Comunidade no domínio do ambiente visa um nível de protecção elevado e é baseada, designadamente, nos princípios da precaução e da acção preventiva (v. acórdão de 11 de Novembro de 2004, Niselli, C-457/02, Colect., p. I-10853, n. ${ }^{\circ} 33$ ).

39 O Tribunal de Justiça também declarou que, atento o objectivo prosseguido pela Directiva 75/442, o conceito de resíduo não pode ser interpretado de maneira restritiva (v. acórdão ARCO Chemie Nederland e o., já referido, n. ${ }^{\circ} 40$ ).

40 Este conceito pode abranger todos os objectos e substâncias de que o proprietário se desfaça, mesmo que tenham valor comercial e sejam recolhidos a título comercial para efeitos de reciclagem, recuperação ou reutilização (v., designadamente, acórdão de 18 de Abril de 2002, Palin Granit e Vehmassalon kansanterveystyön kuntayhtymän hallitus, C 9/oo, Colect., p. I-3533, a seguir «acórdão Palin Granit», n. ${ }^{\circ} 29$ e jurisprudência aí indicada).

41 A este respeito, certas circunstâncias podem constituir indícios da existência de uma acção, de uma intenção ou de uma obrigação de se desfazer de uma substância ou de um objecto, na acepção do artigo $1 .^{\circ}$, alínea a), da Directiva 75/442. Isso acontece, nomeadamente, quando a substância utilizada é um resíduo de produção, ou seja, um produto que não se pretendeu produzir como tal (acórdão ARCO Chemie Nederland e o., já referido, n. ${ }^{05} 83$ e 84). Assim, o Tribunal de Justiça especificou que os detritos da extracção de uma pedreira de granito, que não são a produção principalmente procurada pelo explorador, são, em princípio, resíduos (acórdão Palin Granit, já referido, n. ${ }^{0 s} 32$ e 33 ).

42 Todavia, um objecto, um material ou uma matéria-prima resultantes de um processo de fabrico ou de extracção que não é destinado, em princípio, a produzi los podem constituir não um resíduo mas um subproduto, do qual a empresa não se deseja desfazer, mas que tem a intenção de explorar ou comercializar em condições economicamente vantajosas para ela, num processo posterior, sem qualquer operação de transformação prévia (v. acórdão Palin Granit, já referido, n. ${ }^{\circ}$ 34, e despacho de 15 de Janeiro de 2004, Saetti e Frediani, C 235/02, Colect., p. I 1005, n. ${ }^{3}$ 35).

43 Com efeito, não há justificação alguma para sujeitar às disposições da Directiva 75/442 bens, materiais ou matérias primas que têm economicamente o valor de produtos, independentemente de qualquer transformação, e que, por si mesmos, estão sujeitos à legislação aplicável a estes produtos 
(v. acórdão Palin Granit, já referido, n. ${ }^{\circ}$ 35, e despacho Saetti e Frediani, já referido, n. ${ }^{\circ}$ 35).

44 Todavia, tendo em conta a obrigação de interpretar de forma ampla o conceito de resíduos para limitar os inconvenientes ou prejuízos inerentes à sua natureza, o recurso a esta argumentação relativa aos subprodutos deve circunscrever se às situações em que a reutilização de um bem, de um material ou de uma matéria prima não seja meramente eventual, mas certa, sem transformação prévia, e na continuidade do processo de produção (acórdão Palin Granit, já referido, n. ${ }^{\circ}$ 36, e despacho Saetti e Frediani, já referido, n. ${ }^{3}$ 36).

45 Com o critério que se baseia na natureza ou não de resíduo de produção de uma substância, o grau de probabilidade de reutilização dessa substância, sem operação de transformação prévia, constitui, portanto, um segundo critério pertinente para apreciar se essa substância é ou não um resíduo na acepção da Directiva 75/442. Se, para além da simples possibilidade de reutilizar essa substância, houver para o detentor um benefício económico em fazê lo, a probabilidade de tal reutilização é forte. Nesse caso, a substância em questão não pode ser analisada como uma substância de que o detentor procura "se desfazer», devendo ser considerada como um autêntico produto (v. acórdão Palin Granit, já referido, n. ${ }^{\circ} 37$ ).

46 No processo principal, é patente que a substância em causa é obtida através do processo de refinação do petróleo.

47 Contudo, esta substância residual é susceptível de ser explorada comercialmente, em condições economicamente vantajosas, como o confirma o facto de ter sido objecto de uma transacção comercial e de cumprir as especificações do comprador, como sublinhado pelo órgão jurisdicional de reenvio.

48 Por conseguinte, deve responder se à primeira questão que uma substância com a em causa no processo principal, a saber, o fuelóleo pesado vendido como combustível, não é um resíduo na acepção da Directiva 75/442, dado que é explorada ou comercializada em condições economicamente vantajosas e pode ser efectivamente utilizada como combustível, sem necessidade de uma operação de transformação prévia.

\section{Quanto à segunda questão}

49 Através da sua segunda questão, o órgão jurisdicional de reenvio pretende saber, no essencial, se fuelóleo pesado, acidentalmente derramado no mar na sequência de um naufrágio, deve, nessas circunstâncias, ser qualificado de resíduo na acepção da categoria Q4 do anexo I da Directiva 75/442.

\section{Observações apresentadas ao Tribunal}

50 A autarquia de Mesquer, com quem os Governos francês e italiano e a Comissão, no essencial, concordam, entende que esses hidrocarbonetos, quando são derramados no mar e, por maioria de razão, se misturados com água e sedimentos, devem ser qualificados de resíduos, na acepção da Directiva 75/442.

51 As sociedades Total consideram que a mistura constituída por hidrocarbonetos, água e sedimentos do litoral só é um resíduo se houver uma obrigação de eliminação ou de aproveitamento dos hidrocarbonetos acidentalmente derramados, enquanto tais, e se estes estiverem inextricavelmente ligados à água e aos sedimentos.

520 Governo belga defende que os produtos assim derramados no mar devem ser qualificados, não como resíduos, na acepção da Directiva 75/442, mas como hidrocarbonetos pesados, na acepção da convenção sobre responsabilidade civil e da convenção FIPOL. O Governo do Reino Unido, ao mesmo tempo que admite que esses hidrocarbonetos podem ser qualificados de resíduos, na acepção dessa directiva, considera desejável que o derrame acidental de hidrocarbonetos no mar apenas seja abrangido pelo âmbito da convenção sobre responsabilidade civil e da convenção FIPOL e, por conseguinte, que a Directiva 75/442 não se aplique nestas circunstâncias. 


\section{$\operatorname{RerCED\varrho ̈UA~}$ \\ > Jurisprudência}

\section{Resposta do Tribunal}

53 A título preliminar, importa recordar que o anexo I da Directiva 75/442 propõe listas de substâncias e de objectos que podem ser qualificados como resíduos. Contudo, tem apenas carácter indicativo, dado que a qualificação como resíduo decorre, antes de mais, do comportamento do detentor e do significado da expressão «se desfazer» (v. acórdão de 7 de Setembro de 2004, Van de Walle e o., C-1/03, Colect., p. I-7613, n. $\left.{ }^{\circ} 42\right)$.

54 A circunstância de o anexo I da Directiva 75/442, com o título «Categorias de resíduos», referir no ponto Q4 as «[m]atérias acidentalmente derramadas, perdidas ou que sofreram qualquer outro incidente, incluindo quaisquer matérias, equipamentos, etc., contaminados na sequência do incidente em causa», constitui, assim, apenas um indício da inclusão dessas matérias no âmbito do conceito de resíduo. Por si só, não permite qualificar como resíduos os hidrocarbonetos acidentalmente derramados e que estão na origem da poluição das águas territoriais e, consecutivamente, do litoral de um Estado Membro (v., neste sentido, acórdão Van de Walle e o., já referido, n. ${ }^{\circ} 43$ ).

55 Nestas condições, há que analisar se o referido derramamento acidental de hidrocarbonetos constitui um acto através do qual o detentor se desfaz dos mesmos, na acepção do artigo $1 .^{\circ}$, alínea a), da Directiva 75/442 (v., neste sentido, acórdão Van de Walle e o., já referido, n. ${ }^{4} 44$ ).

56 A este respeito, quando a substância ou o objecto em causa constituem um resíduo de produção, ou seja, um produto que não se pretendeu produzir como tal, com vista à sua utilização posterior, e que o detentor não pode reutilizar, sem transformação prévia, em condições economicamente vantajosas, devem os mesmos ser considerados um peso de que o detentor "se desfaz» (v. acórdão, já referidos, Palin Granit, n. ${ }^{\circ 5} 32$ a 37, e Van de Walle e 0., n. ${ }^{\circ} 46$ ).

57 Relativamente a hidrocarbonetos acidentalmente derramados e que estão na origem da poluição de terras e de águas subterrâneas, o Tribunal de Justiça já teve a oportunidade de declarar que não constituem um produto reutilizável, sem transformação prévia (v. acórdão Van de Walle e o., já referido, $\left.n .^{\circ} 47\right)$.

58 Ora, esta conclusão também se impõe relativamente aos hidrocarbonetos acidentalmente derramados no mar e que estiveram na origem de uma poluição das águas territoriais e, consecutivamente, das costas de um Estado Membro.

59 Efectivamente, é certo que a exploração ou a comercialização desses hidrocarbonetos, derramados ou emulsionados na água, ou ainda misturados com sedimentos, é muito aleatória e até hipotética. Também é um facto que, mesmo admitindo que seja tecnicamente realizável, essa exploração ou comercialização pressuporia sempre operações de transformação prévias que, longe de serem economicamente vantajosas para o detentor de tais substâncias, constituiriam encargos financeiros significativos. Conclui se que esses hidrocarbonetos acidentalmente derramados no mar devem ser considerados substâncias que o detentor não tinha a intenção de produzir e das quais «se desfaz», mesmo que involuntariamente, por ocasião do seu transporte, pelo que têm de ser qualificadas de resíduos, na acepção da Directiva 75/442 (v., neste sentido, acórdão Van de Walle e o., já referido, n. ${ }^{\circ s} 47$ e 50).

60 Além disso, a aplicabilidade da referida directiva não é posta em causa pela circunstância de o derrame acidental de hidrocarbonetos ter ocorrido não no território terrestre de um Estado Membro mas sim na sua zona económica exclusiva.

61 Com efeito, sem que seja necessário apreciar a questão da aplicabilidade dessa directiva ao local do naufrágio, basta sublinhar que os hidrocarbonetos acidentalmente derramados andaram à deriva ao longo do litoral até darem à costa, acabando assim derramados no território desse Estado-Membro. 
62 Donde se conclui que, nas circunstâncias do naufrágio do petroleiro em causa no processo principal, a Directiva 75/442 é aplicável ratione loci.

63 Por conseguinte, deve responder se à segunda questão que os hidrocarbonetos acidentalmente derramados no mar na sequência de um naufrágio, que se encontram misturados na água e em sedimentos e que andaram à deriva ao longo do litoral de um Estado Membro até darem à costa, constituem resíduos, na acepção do artigo 1. $^{\circ}$, alínea a), da Directiva 75/442, uma vez que já não podem ser explorados nem comercializados sem que previamente se proceda a uma operação de transformação.

\section{Quanto à terceira questão}

64 Através da terceira questão, o órgão jurisdicional de reenvio pretende saber se, nas circunstâncias do naufrágio de um petroleiro, o produtor do fuelóleo pesado derramado no mar e/ou o vendedor desse fuelóleo e o afretador do navio que transportava essa substância podem ser obrigados a suportar os custos associados à eliminação dos resíduos assim gerados, quando a substância derramada no mar era transportada por um terceiro, no presente caso, um transportador marítimo

\section{Observações apresentadas ao Tribunal}

65 A autarquia de Mesquer considera que, no processo principal, para efeitos da aplicação do artigo $15 .^{\circ}$ da Directiva 75/442, tanto o produtor do fuelóleo pesado como o vendedor e o afretador do navio que transportava essa substância devem ser considerados, na acepção do artigo $1 .^{\circ}$, alíneas b) e c), dessa directiva, produtores e detentores dos resíduos que resultaram do derrame dessa substância no mar.

66 Segundo as sociedades Total, em circunstâncias como as existentes no processo principal, o artigo $15 .^{\circ}$ da Directiva 75/442 não se aplica nem ao produtor do fuelóleo pesado, nem ao seu vendedor, nem ao afretador do navio que transportava essa substância, dado que esta, no momento em que se deu o acidente que a transformou em resíduos, estava a ser transportada por um terceiro. Por outro lado, esta disposição também não se aplica ao produtor do fuelóleo pesado, pelo simples motivo de este ser o produtor do produto que esteve na origem dos resíduos.

67 Na opinião do Governo francês, a que aderiram parcialmente o Governo italiano e a Comissão, o produtor do fuelóleo pesado e/ou o vendedor desse produto e o afretador do navio que transportava essa substância só podem ser considerados produtores e/ou detentores dos resíduos resultantes do derrame dessa substância no mar, caso o naufrágio do navio, que transformou a carga de fuelóleo pesado em resíduos, seja imputável a actuações susceptíveis de desencadear a sua responsabilidade. A Comissão acrescenta, porém, que o produtor de um produto como o fuelóleo pesado não pode, apenas devido a essa actividade, ser considerado «produtor» e/ou «detentor», na acepção do artigo $1 .^{\circ}$, alíneas b) e c), da Directiva 75/442, dos resíduos gerados por esse produto por ocasião de um acidente ocorrido durante o transporte. Contudo, por força do disposto no artigo $15 .^{\circ}$, segundo travessão, dessa directiva, é obrigado a suportar os custos da eliminação dos resíduos, enquanto «produtor do produto gerador dos resíduos».

68 Para o Governo belga, é de afastar a aplicação da Directiva 75/442 pelo facto de se aplicar a convenção sobre responsabilidade civil. Do mesmo modo, o Governo do Reino Unido considera que o Tribunal de Justiça não deve responder a esta questão, dado que o processo principal versa sobre questões de responsabilidade decorrentes de um derrame de fuelóleo no mar.

\section{Resposta do Tribunal}

69 Em circunstâncias como as do processo principal, atento o objectivo da Directiva 75/442 como recordado no seu terceiro considerando, o artigo $15 .^{\circ}$, segundo travessão, dessa directiva prevê que, em conformidade com o princípio do poluidor pagador, os custos da eliminação dos resíduos devem ser suportados pelos detentores anteriores ou pelo produtor do produto gerador dos resíduos. 


\section{RerCED光UA}

> Jurisprudência

70 Por força do artigo $8 .^{\circ}$ da Directiva 75/442, «qualquer detentor de resíduos» é obrigado quer a confiar a sua manipulação a um serviço de recolha privado ou público, ou a uma empresa que efectue as operações referidas no anexo II A ou II B da directiva, quer a proceder ele próprio ao respectivo aproveitamento ou eliminação, em conformidade com o disposto na referida directiva (acórdão de 26 de Abril de 2005, Comissão/Irlanda, C-494/01, Colect., p. I-3331, n. ${ }^{\circ} 179$ ).

71 Resulta das disposições referidas que a Directiva 75/442 distingue a realização material das operações de valorização ou de eliminação, que impõe a qualquer «detentor de resíduos», quer ele seja o produtor ou o possuidor dos mesmos, da assunção da responsabilidade financeira pelas referidas operações, que ela imputa, em conformidade com o princípio do poluidor pagador, às entidades que deram origem aos resíduos, quer estas sejam detentoras ou anteriores detentoras dos mesmos, ou ainda produtoras do produto gerador dos resíduos (acórdão Van de Walle e o., já referido, n. ${ }^{\circ}$ 5).

72 A este respeito, a aplicação do princípio do poluidor pagador, na acepção do artigo $174 .^{\circ}$, n. $^{\circ}$ 2, primeiro parágrafo, segundo período, CE e do artigo $15 .^{\circ}$ da Directiva $75 / 442$, seria posta em causa se essas entidades que estiveram implicadas na produção dos resíduos pudessem escapar às suas obrigações financeiras, como as previstas na Directiva 75/442, quando está claramente demonstrada a origem dos hidrocarbonetos derramados no mar, embora involuntariamente, que estiveram na origem da poluição do território costeiro de um Estado Membro.

- Quanto aos conceitos de «detentor» e de «detentores anteriores»

730 Tribunal entendeu, no que respeita a hidrocarbonetos acidentalmente derramados, provenientes de uma fuga nas instalações de armazenagem de uma estação de serviço, que tinham sido por esta adquiridos para as necessidades da sua exploração, que esses hidrocarbonetos estavam, efectivamente, na posse do gerente da estação de serviço. O Tribunal considerou assim que, nesse contexto, quem, para as necessidades da sua actividade, armazenava esses hidrocarbonetos quando se tornaram resíduos, pode ser considerado aquele que os «produziu», na acepção do artigo 1. ${ }^{\circ}$, alínea b), da Directiva 75/442. Com efeito, uma vez que, simultaneamente, é o possuidor e o produtor desses resíduos, o gerente dessa estação de serviço deve ser considerado o detentor dos resíduos, na acepção do artigo $1 .^{\circ}$, alínea c), dessa directiva (v., neste sentido, acórdão Van de Walle e o., já referido, n. ${ }^{\circ} 59$ ).

74 Da mesma forma, quanto a hidrocarbonetos acidentalmente derramados no mar, importa sublinhar que o proprietário do navio que os transportava está, efectivamente, na posse dos mesmos, imediatamente antes de se tornarem resíduos. Nestas condições, o proprietário do referido navio pode, portanto, ser considerado como tendo produzido os referidos resíduos, na acepção do artigo 1. ${ }^{\circ}$, alínea b), da Directiva 75/442, e, a esse título, ser assim qualificado de «detentor», na acepção do artigo 1. ${ }^{\circ}$, alínea c), desta directiva.

75 Todavia, a referida directiva não exclui que, em determinadas situações, os custos da eliminação dos resíduos fiquem a cargo de um ou de vários detentores anteriores (acórdão Van de Walle e o., já referido, n. ${ }^{\circ}$ 57).

- Quanto à determinação de quem deve suportar os custos da eliminação dos resíduos

76 No processo principal, a questão que se coloca é a de saber se quem vendeu a mercadoria ao destinatário final e, para esse efeito, afretou o navio que naufragou no mar também pode ser considerado «detentor», e a esse título «detentor anterior», dos resíduos assim derramados. Além disso, o órgão jurisdicional de reenvio interroga se sobre se o produtor do produto que gerou esses resíduos também pode ser obrigado a suportar os custos da eliminação dos resíduos assim gerados.

77 A este respeito, o artigo $15 .^{\circ}$ da Directiva 75/442 dispõe que determinadas categorias de pessoas, no presente caso, os «detentores anteriores» ou o «produtor do produto gerador», podem, em conformidade com o princípio do poluidor pagador, ser obrigadas a suportar os custos da eliminação dos resíduos. Assim, cabe lhes esta obrigação financeira devido ao facto de terem contribuído para a produção dos referidos resíduos e, eventualmente, para o risco de poluição daí resultante. 
78 Por conseguinte, quanto aos hidrocarbonetos derramados acidentalmente no mar na sequência do naufrágio de um petroleiro, o órgão jurisdicional nacional pode considerar que o vendedor desses hidrocarbonetos e afretador do navio que os transportava «produziu resíduos», se esse órgão jurisdicional, face aos elementos que só ele está em condições de apreciar, chegar à conclusão de que esse vendedor/ afretador contribuiu para o risco da ocorrência de poluição ocasionada por esse naufrágio, especialmente se não tomou medidas destinadas a prevenir esse acontecimento, como as relativas à escolha do navio. Nessas circunstâncias, o referido vendedor/afretador poderá ser considerado o detentor anterior dos resíduos, para efeitos da aplicação do artigo $15 .^{\circ}$, segundo travessão, primeira parte, da Directiva 75/442.

79 Como foi recordado no n. ${ }^{\circ} 69$ do presente acórdão, nas circunstâncias do processo principal, o artigo $15 .^{\circ}$, segundo travessão, da Directiva 75/442 prevê, através da utilização da conjunção «ou», que os custos da eliminação dos resíduos devem ser suportados pelos «detentores anteriores» ou pelo «produtor do produto gerador» dos resíduos em questão.

80 A este propósito, em conformidade com o disposto no artigo $249 .{ }^{\circ} \mathrm{CE}$, os Estados Membros destinatários da Directiva 75/442, embora sejam competentes quanto à forma e aos meios, estão vinculados quanto ao resultado a alcançar em termos de assunção do encargo financeiro dos custos ligados à eliminação dos resíduos. Por conseguinte, são obrigados a assegurar se de que o seu ordenamento jurídico nacional permite a imputação dos referidos custos aos detentores anteriores ou ao produtor do produto gerador dos resíduos.

81 Como a advogada geral referiu no n. ${ }^{\circ} 135$ das suas conclusões, o artigo $15 .^{\circ}$ da Directiva 75/442 não se opõe a que os Estados Membros prevejam, ao abrigo de compromissos internacionais assumidos na matéria, como a convenção sobre responsabilidade civil e a convenção FIPOL, que o proprietário do navio e o seu afretador só respondam pelos prejuízos causados pelo derrame de hidrocarbonetos no mar, até ao limite dos montantes definidos em função da arqueação do navio e/ou em circunstâncias particulares decorrentes da sua conduta negligente. Esta disposição também não se opõe a que, em aplicação dos referidos compromissos internacionais, um fundo internacional, como o FIPOL, com recursos limitados para cada sinistro, assuma, em vez dos «detentores», na acepção do artigo $1^{\circ}{ }^{\circ}$, alínea c), da Directiva 75/442, os custos associados à eliminação dos resíduos resultantes de hidrocarbonetos acidentalmente derramados no mar.

82 Todavia, caso se verifique que os custos associados à eliminação dos resíduos gerados pelo derrame acidental de hidrocarbonetos no mar não são assumidos pelo referido fundo ou não o podem ser devido ao esgotamento do limite da indemnização previsto para esse sinistro e que, por força das limitações e/ou das isenções de responsabilidade previstas, o direito nacional de um Estado Membro, incluindo o direito resultante das convenções internacionais, obsta a que esses custos sejam suportados pelo proprietário do navio e/ou pelo seu afretador, embora estes sejam considerados «detentores» na acepção do artigo 1. ${ }^{\circ}$, alínea c), da Directiva 75/442, esse direito nacional deverá então permitir, para assegurar uma transposição conforme do artigo $15 .{ }^{\circ}$ da directiva, que os referidos custos sejam suportados pelo produtor do produto gerador dos resíduos assim derramados. No entanto, em conformidade com o princípio do poluidor pagador, esse produtor só pode ser obrigado a suportar esses custos se, devido à sua actividade, contribuiu para o risco de ocorrência da poluição ocasionada pelo naufrágio do navio.

83 A este respeito, a obrigação de um Estado Membro adoptar todas as medidas necessárias para alcançar o resultado imposto por uma directiva é uma obrigação vinculativa imposta pelo artigo 249. , terceiro parágrafo, CE e pela própria directiva. Esta obrigação de tomar todas as medidas gerais ou especiais é imposta a todas as autoridades dos Estados Membros, incluindo, no âmbito das suas competências, os órgãos jurisdicionais (v. acórdãos de 13 de Novembro de 1990, Marleasing, C-106/89, Colect., p. I-4135, n. ${ }^{\circ}$, e Inter-Environnement Wallonie, já referido, n. ${ }^{40}$ ).

84 Daqui resulta que, ao aplicar o direito nacional, quer se trate de disposições anteriores ou posteriores à directiva ou de disposições resultantes de convenções internacionais subscritas pelo Estado Membro, o órgão jurisdicional nacional chamado a interpretá lo é obrigado a fazê lo, na 
medida do possível, à luz do texto e da finalidade da directiva, para atingir o resultado por ela prosseguido e cumprir desta forma o artigo $249 .^{\circ}$, terceiro parágrafo, CE (v., neste sentido, acórdão Marleasing, já referido, n. ${ }^{\circ}$ ).

85 Além disso, contrariamente ao que as sociedades Total sustentaram na audiência, a Comunidade não está vinculada pela convenção sobre responsabilidade civil nem pela convenção FIPOL. Com efeito, por um lado, a Comunidade não aderiu aos referidos instrumentos internacionais e, por outro, não se pode considerar que substituiu os seus Estados Membros, quanto mais não seja porque nem todos são parte nas referidas convenções (v., por analogia, acórdãos de 14 de Julho de 1994, Peralta, C-379/92, Colect., p. I-3453, n. ${ }^{\circ} 16$; e de 3 de Junho de 2008, Intertanko e 0., C-308/06, ainda não publicado na Colectânea, n. ${ }^{\circ}$ 47), nem que está indirectamente vinculada pelas referidas convenções por força do artigo $235 .^{\circ}$ da Convenção das Nações Unidas sobre o Direito do Mar, assinada em Montego Bay, em 10 de Dezembro de 1982, que entrou em vigor em 16 de Dezembro de 1994, e aprovada pela Decisão 98/392/CE do Conselho de 23 de Março de 1998 (JO L 179, p. 1), disposição esta cujo n. ${ }^{\circ} 3$ se limita, como o Governo francês sublinhou na audiência, a estabelecer uma obrigação geral de cooperação entre as partes na referida convenção.

86 Além disso, relativamente à Decisão 2004/246, que autoriza os Estados Membros a assinar ou a ratificar, no interesse da Comunidade, o protocolo de 2003 à convenção FIPOL, ou a aderir a esse instrumento, basta assinalar que a referida decisão e o referido protocolo de 2003 não são aplicáveis aos factos em causa no processo principal.

87 É verdade que a Directiva 2004/35 prevê expressamente, no artigo $4 .^{\circ}$, n. ${ }^{\circ}$ 2, que não se aplica a incidentes ou a actividades relativamente às quais a responsabilidade ou a compensação sejam abrangidas pelo âmbito de aplicação de um dos instrumentos internacionais enumerados no seu anexo IV, que refere a convenção sobre responsabilidade civil e a convenção FIPOL. Com efeito, o legislador comunitário, como é referido no décimo considerando dessa directiva, considerou necessário deverem ser expressamente tidas em conta as convenções internacionais pertinentes que regulem de forma mais abrangente e rigorosa o exercício de quaisquer actividades incluídas no âmbito dessa directiva.

88 Contudo, importa reconhecer que a Directiva 75/442 não contém uma disposição análoga, mesmo na versão codificada resultante da Directiva 2006/12.

89 Atentas as considerações que precedem, deve responder se à terceira questão que, para efeitos da aplicação do artigo $15 .^{\circ}$ da Directiva 75/442 ao derrame acidental de hidrocarbonetos no mar, que está na origem da poluição da costa de um Estado Membro:

- o órgão jurisdicional nacional pode considerar que o vendedor desses hidrocarbonetos e afretador do navio que os transportava é o produtor desses resíduos, na acepção do artigo $1 .^{\circ}$, alínea b), da Directiva 75/442, e, ao proceder deste modo, também o «detentor anterior», para efeitos da aplicação do artigo $15 .^{\circ}$, segundo travessão, primeira parte, dessa directiva, se esse órgão jurisdicional, face aos elementos que só ele está em condições de apreciar, chegar à conclusão de que esse vendedor afretador contribuiu para o risco de ocorrência da poluição ocasionada por esse naufrágio, especialmente se não tomou as medidas destinadas a prevenir esse acontecimento, como as relativas à escolha do navio;

- caso se verifique que os custos associados à eliminação dos resíduos gerados pelo derrame acidental de hidrocarbonetos no mar não são assumidos pelo FIPOL ou não o podem ser devido ao esgotamento do limite de indemnização previsto para esse sinistro e que, por força das limitações e/ ou das isenções de responsabilidade previstas, o direito nacional de um Estado Membro, incluindo o direito resultante das convenções internacionais, obsta a que esses custos sejam suportados pelo proprietário do navio e/ou pelo seu afretador, embora estes sejam considerados «detentores» na acepção do artigo $1 .^{\circ}$, alínea c), da Directiva 75/442, esse direito nacional deverá então permitir, para assegurar uma transposição conforme do artigo $15 .^{\circ}$ dessa directiva, que os referidos custos sejam suportados pelo produtor do produto gerador dos resíduos assim derramados. No entanto, em conformidade com o princípio do poluidor pagador, esse produtor só pode ser obrigado a suportar esses custos se, devido à sua actividade, contribuiu para o risco de ocorrência da poluição ocasionada pelo naufrágio do navio. 
Quanto às despesas

90 Revestindo o processo, quanto às partes na causa principal, a natureza de incidente suscitado perante o órgão jurisdicional de reenvio, compete a este decidir quanto às despesas. As despesas efectuadas pelas outras partes para a apresentação de observações ao Tribunal de Justiça não são reembolsáveis.

Pelos fundamentos expostos, o Tribunal de Justiça (Grande Secção) declara:

1) Uma substância como a que está em causa no processo principal, a saber, o fuelóleo pesado vendido como combustível, não é um resíduo na acepção da Directiva 75/442/CEE do Conselho, de 15 de Julho de 1975, relativa aos resíduos, alterada pela Decisão 96/350/CE da Comissão, de 24 de Maio de 1996, dado que é explorada ou comercializada em condições economicamente vantajosas e pode ser efectivamente utilizada como combustível, sem necessidade de uma operação de transformação prévia.

2) Os hidrocarbonetos acidentalmente derramados no mar na sequência de um naufrágio, que se encontram misturados na água e em sedimentos e que andaram à deriva ao longo do litoral de um Estado Membro até darem à costa, constituem resíduos, na acepção do artigo 1. ${ }^{\circ}$, alínea a), da Directiva 75/442, alterada pela Decisão 96/350, uma vez que já não podem ser explorados nem comercializados sem que previamente se proceda a uma operação de transformação.

3) Para efeitos da aplicação do artigo $15 .^{\circ}$ da Directiva $75 / 442$, alterada pela Decisão 96/350, ao derrame acidental de hidrocarbonetos no mar, que está na origem da poluição da costa de um Estado Membro:

- o órgão jurisdicional nacional pode considerar que o vendedor desses hidrocarbonetos e afretador do navio que os transportava é o produtor desses resíduos, na acepção do artigo 1. ${ }^{\circ}$, alínea b), da Directiva 75/442, alterada pela Decisão 96/350, e, ao proceder deste modo, também o «detentor anterior", para efeitos da aplicação do artigo $15 .^{\circ}$, segundo travessão, primeira parte, dessa directiva, se esse órgão jurisdicional, face aos elementos que só ele está em condições de apreciar, chegar à conclusão de que esse vendedor afretador contribuiu para o risco de ocorrência da poluição ocasionada por esse naufrágio, especialmente se não tomou as medidas destinadas a prevenir esse acontecimento, como as relativas à escolha do navio;

- caso se verifique que os custos associados à eliminação dos resíduos gerados pelo derrame acidental de hidrocarbonetos no mar não são assumidos pelo Fundo Internacional para compensação pelos prejuízos devidos à poluição por hidrocarbonetos ou não o podem ser devido ao esgotamento do limite de indemnização previsto para esse sinistro e que, por força das limitações e/ou das isenções de responsabilidade previstas, o direito nacional de um Estado Membro, incluindo o direito resultante das convenções internacionais, obsta a que esses custos sejam suportados pelo proprietário do navio e/ou pelo seu afretador, embora estes sejam considerados «detentores» na acepção do artigo 1. ${ }^{\circ}$, alínea c), da Directiva 75/442, alterada pela Decisão 96/350, esse direito nacional deverá então permitir, para assegurar uma transposição conforme do artigo $15 .^{\circ}$ dessa directiva, que os referidos custos sejam suportados pelo produtor do produto gerador dos resíduos assim derramados. No entanto, em conformidade com o princípio do poluidor pagador, esse produtor só pode ser obrigado a suportar esses custos se, devido à sua actividade, contribuiu para o risco de ocorrência da poluição ocasionada pelo naufrágio do navio.

* Língua do processo: francês. 


\section{Poluição marinha, hidrocarbonetos e resíduos (O caso do Erika no TJCE)}

1 - À jurisprudência relativa à indemnização por danos causados por poluição marítima devida ao derramamento no mar de hidrocarbonetos a partir de navios ${ }^{1}$, veio, não há muito, juntar-se uma nova decisão: o acórdão de 24 de Junho de 2008 do Tribunal de Justiça das Comunidades Europeias (TJCE) ${ }^{2}$. Creio que essa decisão é susceptível de influenciar a aplicação judiciária da disciplina jurídica-internacional do que poderá denominar-se de sistema indemnizatório CLC/92-Fipol’3. Que assim é, prova-o o acórdão da 3. ${ }^{\text {a }}$ secção civil, de 17 de Dezembro de 2008 , da Cour de Cassation francesa (CCass) ${ }^{4}$ que ordenou, revogando a anterior decisão da Cour d’Appel de Rennes, a remessa do processo à Cour d’Apppel de Bordeaux para novo julgamento que tivesse em atenção a decisão do aresto do TJCE. Justifica-se, pois, passar em revista as soluções desse aresto, de modo a avaliar o seu impacto no referido sistema ressarcitório e, não menos importante, no direito do ambiente.

Recorde-se o factualismo presente ao aresto do TJCE. A 12 de Dezembro de 1999, o navio-tanque Erika, atingido por um forte temporal ao largo da costa da Bretanha, partiuse em dois derramando cerca de 19.800 toneladas de hidrocarbonetos que poluíram cerca de 450 quilómetros de costas $^{5}$. As vítimas foram indemnizadas ao abrigo do sistema indemnizatório CLC-92/Fipol. Porém, uma delas - a Commune de Mesquer - considerando que esse sistema não reparara todos os danos por si sofridos propôs contra "Total France, S.A." e "Total International Ltd", uma acção pedindo que as mesmas fossem condenadas in solidum a pagar as despesas que suportara com a limpeza e despoluição do território

\footnotetext{
${ }^{1}$ Essa jurisprudência, hoje abundante, formou-se a partir de incidentes com navios-tanque causadores de catástrofes ambientais, como v.g. os sinistros com o Torrey Canion (1967), com o Amoco Cadiz (1978) com o Exxon Valdez (1989) e mais recentemente, com o Erika (1999) - de que aqui nos ocupamos - ou com o Prestige (2000). Em Portugal deve assinalar-se o caso do Marão (1989) decidido pelo acórdão de 20 de Outubro de 1994 do Tribunal da Relação de Lisboa, Colectânea de Jurisprudência, Ano XIX, Tomo IV, págs, 125 e segts, passim; Sobre esta decisão cfr. JORGE SINDE MONTEIRO, A Protecção dos Interesses Económicos na responsabilidade civil por dano ambiental, in A Tutela Jurídica do Meio Ambiente Presente e Futuro, Stvdia Jurídica, 81, Universidade de Coimbra, Coimbra Editora, Coimbra, 2005, págs. 139 e segts., passim. Também me ocupei deste importante acórdão no meu Poluição Marítima e Responsabilidade Civil, Almedina, Coimbra, 2007, pág. 61.

${ }^{2}$ Commune de Masquer v. Total et Total France; Proc. ‥ำ188/07, acórdão de 24 de Junho de 2008; Journal officiel de l’Union Européenne de 15.8.2008; texto não oficial do aresto em http://eur-lex.europa.eu /JURISIndex.do.

${ }^{3} \mathrm{O}$ que denomino pelas expressões sistema indemnizatório, CLC/-Fipol ou sistema de Londres é constituído por duas convenções internacionais, Convenção Internacional sobre a responsabilidade civil pelos prejuízos causados por hidrocarbonetos, aprovado para ratificação pelo Decreto n.ำ 40/2001, de 21 de Setembro, Diário da República n.ำ 226/2001 Série I-A de 28 de Setembro de 2001 (CLC/92); Convenção Internacional para o estabelecimento de um Fundo Internacional para a compensação pelos prejuízos devidos à poluição por hidrocarbonetos, versão de 1992, aprovado para ratificação pelo Decreto n.. 38/2001, de 28 de Setembro, Diário da República n.. 223/2001 Série I-A de 25 de Setembro de 2001 (Fipol). Com as referidas designações, reconhece-se tão só a vocação das convenções CLC e Fipol para uma aplicação conjunta, aliás, expressamente desejada pelos autores das convenções. De facto, na obtenção de acordo sobre os traços definitórios da anterior versão (1969) de que a CLC/92 é uma versão actualizada, foi determinante a aceitação da criação de um Fundo que pudesse aumentar os tectos ressarcitórios das indemnizações a pagar aos lesados em caso de acidentes - derramamentos no mar de hidrocarbonetos a partir de navios - que dessem lugar a somas que os meios proporcionados pela CLC/92 não conseguissem suportar. O Fipol encontra-se, pois, genética e funcionalmente ligado à CLC. Daí, ao longo deste texto, o uso da expressão sistema indemnizatório CLC/92-Fipol; Sobre toda esta temática, cfr., MICHAEL M` GONIGLE e MARK ZACHER, Pollution, Politics, and International Law, Tankers at Sea, University of California Press, 1979, pág. 173. Haverá oportunidade de, mais adiante, descrever as características mais salientes do sistema indemnizatório CLC/92-Fipol.

4 Publicado em http://www.courdecassation.fr/jurisprudence 2/troisiemechambrecivile572/

${ }_{5}$ Informações disponíveis em http://fr.iopcfund.org/erika.htm.
} 


\section{RerCED光UA

comunal. As duas sociedades referidas eram, respectivamente, a vendedora e a dona da carga transportada no Erika derramada no mar. Os fundamentos jurídicos do pedido eram constituídos pela lei francesa sobre resíduos que introduzira a directiva 775/442/CE e pelo disposto na alínea 1 do artigo 1384 do Código Civil francês ${ }^{6}$.

Em 1. a instância o Tribunal de Saint Nazaire absolveu as rés. Em recurso, a questão foi objecto de novo exame pela Cour d’Appel de Rennes que por aresto de 13 de Fevereiro de 2002, confirmou a decisão recorrida ${ }^{7}$. Nesta o tribunal de recurso defendeu que 0 fuelóleo pesado n.ำ 2 não é um resíduo, antes um produto cujo destino desde o início “...era a utilização directa como combustível para necessidades de produção eléctrica”. Quanto a saber se teria havido culpa na guarda de um produto perigoso, dando lugar à violação do disposto no artigo 1384/1 do Code Civil, o tribunal, muito simplesmente constatou que "...o fuelóleo não desempenhou qualquer papel nos acontecimentos de mar”. Perante esta decisão a Commune de Masquer interpôs recurso para a CCass que, em reenvio prejudicial, solicitou ao TJCE que se pronunciasse sobre três questões. Antes de as enumerar convém saber quais as razões factuais que explicam as perguntas da CCass. A Cour d'Appel mantivera-se nos estritos limites do sistema CLC/Fipol recusando-se a ver nos hidrocarbonetos derramados resíduos. Daí decorria a possibilidade da Commune de Masquer não ser indemnizada de todos os danos que sofrera, dada a insuficiência de meios desse sistema. Coincidisse o valor da compensação recebida pela autora ao abrigo do sistema de Londres com o montante dos danos sofridos pela autora nunca a questão teria surgido. Perante essa circunstância, o único meio de ultrapassar os constrangimentos aludidos do sistema CLC-92/Fipol seria encarar o assunto sob diferente prisma de modo a permitir elevar as indemnizações a arbitrar aos lesados. Uma visão alternativa - de que a disciplina comunitária sobre resíduos é exemplo - possibilitaria demandar outros responsáveis, não susceptíveis de o ser no sistema CLC/Fipol. Embora o debate no TJCE girasse em torno da possibilidade de fazer caber no conceito de resíduo, tal como elaborado na normativa comunitária, os hidrocarbonetos misturados com água e sedimentos, creio não ser essa a questão fulcral. Julgo, antes, que, mesmo que apenas subliminarmente, os intervenientes no processo conheciam a insuficiência do regime do dito sistema CLC/ Fipol no que tem a ver com os meios materiais para suportar as indemnizações. Esse facto acabou por trazer para o debate a Directiva 75/442. Suscitando-se, porém, dúvidas na sua interpretação, a CCass submeteu à apreciação do TJCE as três seguintes questões:

1) O fuelóleo pesado, produto resultante de um processo de refinação, de acordo com as especificações do utilizador, destinado pelo produtor a ser vendido como combustível e mencionado na Directiva 68/414 [...] pode ser qualificado de resíduo, na acepção do artigo $1 .{ }^{\circ}$ da Directiva $75 / 442^{8}[\ldots]$ codificada pela Directiva 2006/12 [...]?

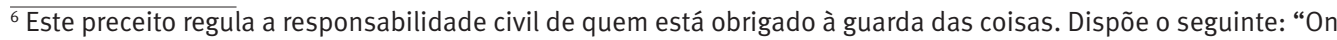
est responsable non-seulement du dommage que l' on cause par son propre fait, mais encore de celui qui est causé par le fait des personnes dont on doit répondre, ou des choses que l' on a sous sa garde". A jurisprudência francesa considera este preceito aplicável a navios. Contudo, dado que a França é parte na CLC/92, que exclui o afretador do navio das entidades responsáveis pelos danos, penso que este preceito era inaplicável ao caso do Erika caso julgado nos tribunais de Estados - caso da França - aderentes ao sistema CLC/Fipol.

7 Deuxième Chambre Comm, ARRET № 70, R. G : 00/08026; COMMUNE DE MESQUER C/S.A. TOTAL RAFFINAGE DISTRIBUTION Société TOTAL INTERNATIONAL LTD

${ }^{8}$ Segundo o texto oficial francês que segui porque o pedido de decisão prejudicial foi apresentado pela Cour de Cassation francesa, "une cargaison de filoul lourd, transportée para un navire et accidentellement déversée dans la mer constitue-t-elle par elle même. ou du fait de son mélange à l'eau et à des sédiments, un déchet au sens ad la rubrique Q 4 de l’annexe I de la directive 2006/12/CE?”; JO, [FR] 9.6.2007.
} 


\section{$\operatorname{RerCEDळ̈UA~}$}

> Jurisprudência

2) Uma carga de fuelóleo pesado, transportada por um navio e acidentalmente derramada no mar, constitui, em si mesma ou em virtude da sua mistura com água e sedimentos, um resíduo na acepção [da categoria] Q4 do anexo I da Directiva 2006/12 [...]?

3) Em caso de resposta negativa à primeira questão e positiva à segunda, o produtor do fuelóleo pesado (Total raffinage [distribution]) e/ou o vendedor e afretador (Total international Ltd) podem ser considerados, na acepção do artigo $1 .^{\circ}$, alíneas b) e c), da Directiva 2006/12 [...] e para efeitos da aplicação do artigo $15 .^{\circ}$ da mesma directiva, produtores e/ou detentores do resíduo, apesar de, no momento do acidente que o transformou em resíduo, o produto ser transportado por um terceiro [no presente caso, um transportador marítimo $\left.{ }^{9}\right]$ ?

A razão de ser das perguntas colocadas ao TJCE decorre em boa medida do quadro fáctico presente no caso do Erika. Os acidentes habituais com petroleiros, situação típica que os autores iniciais da Convenção de 1992 tinham em mente na sua redacção, caracterizam-se por um derramamento de hidrocarbonetos que, escapando do navio, contaminam o mar e a sua orla costeira não perdendo a sua natureza própria e específica de hidrocarbonetos líquidos, mesmo no momento da contaminação. No caso do Erika, porém, os hidrocarbonetos ainda no mar e antes de atingir as praias, fundiram-se de modo inextricável com sedimentos arenosos, produzindo um produto misto assimilável a um resíduo. Assim, podia pôr-se a questão de saber se, após esse processo químico natural, a disciplina jurídica da indemnização ainda seria a dos hidrocarbonetos ou se não se justificaria antes colocar o problema da indemnização em sede de resíduos. 0 que precede permite avaliar o impacto da opção por um ou por outro dos regimes potencialmente aplicáveis. Direi, antecipando o que se segue, que o TJCE preconizou a aplicação simultânea dos dois regimes ou seja, o sistema de Londres complementado, quando e se isso se tornar necessário, para obter o integral ressarcimento integral dos danos, com a normativa comunitária sobre resíduos.

2 - Vejamos, pois, as respostas dadas pelo TJCE às questões prejudiciais que the haviam sido suscitadas pela CCass. A primeira e a segunda respostas às questões prejudiciais, como que se complementam ainda que a mesma tenha recebido uma resposta negativa e a segunda uma resposta afirmativa. De facto, após na 1. ․ resposta se dizer que o “... fuelóleo pesado vendido como combustível não é um resíduo”, logo na 2.ㄹ resposta o tribunal precisa essa sua resposta dizendo que, "Os hidrocarbonetos acidentalmente derramados no mar na sequência de um naufrágio, que se encontram misturados na água e em sedimentos e que andaram à deriva ao longo do litoral de um Estado-membro até darem à costa, constituem resíduos...”. Nestas respostas nada há que, verdadeiramente, possa considerar-se novo relativamente à disciplina do sistema ressarcitório CLC/FIPOL, a cujas convenções o TJCE, aliás, alude ao ocupar-se do modo como devem ser articuladas no que poderá designar-se, latu sensu, o sistema ressarcitório de dano ecológico que procura reconstruir, no espaço europeu.

A resposta dada à terceira questão preliminar pode ser dividida em duas partes complementares entre si. Na primeira, o tribunal nota que o juiz nacional pode considerar o vendedor e afretador do navio transportador como produtor dos ditos resíduos, no sentido do artigo 1. - a alínea b) da directiva 75/442, tal como modificada pela decisão 96/350. Ao fazê-lo, o juiz nacional pode considerar que o vendedor-afretador o fez na qualidade de

${ }^{9} \mathrm{O}$ outro pedido de decisão prejudicial pretendia saber se, “....le producteur du fioul (...) et/ou le vendeur et affréteur (...) Peuvent ils être considérées au sens des articles 1er, sous b) et c) de la directive 2006/12/Ce et pour l'application de l'article 15 de la même directive comme producteur et/ou détenteur du déchet alors qu' au moment de l'accident qui l’a transformé au déchet le produit était transporté par un tiers?”; JO, [FR] 9.6.2007. 
detentor anterior, para fins da aplicação da primeira parte da alínea segunda do artigo 15 dessa directiva, se concluir que contribuiu para o risco da ocorrência da poluição ocasionada pelo naufrágio, em especial se o mesmo omitiu as medidas visando a prevenção de um tal evento, tais como, v.g., as respeitantes à escolha do petroleiro ${ }^{10}$. 0 efeito prático do raciocínio judicial indicado é, consequentemente, o de tornar aplicável ao caso do Erika o artigo 15.\%/alínea b) da directiva 75/442, disposição segundo a qual os custos da eliminação dos resíduos devem ser suportados, "Pelos detentores anteriores ou pelo produtor do produto gerador dos resíduos". Na segunda parte da resposta, o tribunal complementa o alcance da doutrina enunciada na primeira parte. Uma vez situada a questão em sede de resíduos o recurso a esse regime obedece a três requisitos:

(a) Os custos ligados à eliminação dos resíduos gerados por um derramamento acidental de hidrocarbonetos no mar não serem suportados pelo Fipol, (b) Os tectos ressarcitórios do Fipol terem sido atingidos e (c) estar presente uma situação de exoneração legal, provinda de convenções internacionais que impedem a responsabilização do proprietário ou do afretador. Segundo o TJCE, nestas situações o direito nacional deverá permitir, para assegurar a transposição do artigo 15 da directiva 754/442, que “...os ditos custos sejam suportados pelo produtor do produto gerador dos resíduos derramados" ${ }^{11}$. Estas três condições, por sua vez estão sujeitas a duas ressalvas. (a) A responsabilidade civil do produtor dos resíduos - a dever ser aferida à luz do princípio poluidor-pagador - terá de estar ligada a uma actuação sua que tenha contribuído para o risco de poluição.

(b) A segunda ressalva complementa a primeira pois o efeito jurídico da presunção de responsabilidade do produtor dos resíduos é de inverter o ónus da prova. Porém, regendose a apreciação do risco criado pelo produtor, segundo o tribunal, pelo regra poluidorpagador, serão aplicadas as regras relativas a este último princípio.

3 - Perpassa nesta decisão a intenção de alargar os meios materiais colocados à disposição do lesado através do aumento do número de potenciais responsáveis perante o mesmo. Deste modo, fortalece a posição de quem pretende concretizar a reparação dos danos que the forem causados por poluição marítima por hidrocarbonetos provindos de navios. Não se trata tanto de pôr em causa o sistema de Londres mas antes de, indo para além dele, admitir accionar outros potenciais responsáveis cíveis. De facto, mais do que pretender pôr em causa esse sistema, quer admitir outras formas de indemnizar ${ }^{12}$, que complementem os meios do Fipol. Que é de uma lógica de complementaridade que se trata decorre da passagem do acórdão em que este afirma que o direito nacional deverá permitir, para assegurar a transposição do artigo 15 da directiva 754/442, que "...os ditos custos sejam suportados pelo produtor do produto gerador dos resíduos derramados" (producteur du produit générateur des déchets ainsi répandus) se não conseguir obter o ressarcimento de todos os danos que tiver sofrido. De acordo com as alíneas b) e c) do artigo 1.. da directiva consideram-se, respectivamente, produtor (a) aquele cuja actividade

${ }^{10}$ Transcreve-se o texto completo na língua francesa, lingua oficial, «...le juge national peut considérer le vendeur de ces hydrocarbures et affréteur du navire les transportant comme producteur des dits déchets, au sens de l'article 1er, sous b), de la directive 75/442, telle que modifiée par la décision 96/350 et ce faisant, comme «détenteur antérieur» aux fins de l' application de l'article 15, second tiret, première partie, de cette directive si ce juge, au vu des éléments qui lui seul est à même d'apprécier, aboutit à conclusion que ce vendeur-affréteur a contribué au risque de la survenance de la pollution occasionnée par ce naufrage, en particulier s`il s`est abstenu de prendre les mesures visant à prévenir un tel événement telles celles concernant le choix du navire».

${ }^{11}$ No texto francês escreve-se : “...que les dits coûts soient supportées par le producteur do produit générateur des déchets ainsi répandus".

${ }^{12} \mathrm{Em}$ abono da verdade não pode, contudo, excluir-se que o posicionamento do TJCE, em certa medida seja condicionado pelo modo pelo qual as questões prejudiciais lhe são colocadas. De qualquer modo o aresto aceita a possibilidade das partes escolherem, para além da normativa internacional, qualquer outro título de aquisição, designadamente o do direito interno. 
produza resíduos ou quem efectue operações de pré-tratamento que conduzam a uma alteração da natureza ou da composição desses resíduos e detentor (b) o produtor dos resíduos ou a pessoa singular ou colectiva que tem os resíduos na sua posse. Em face destas definições o Tribunal de Justiça defendeu ser possível “...considerar que o vendedor desses hidrocarbonetos e afretador do navio que os transportava é o produtor desses resíduos, na acepção do artigo 1.․․ da Directiva 754/442, alterada pela Decisão 96/350, e, ao proceder deste modo, também o «detentor anterior», para efeitos da aplicação do artigo 15. - , segundo travessão, primeira parte, dessa directiva, se esse órgão jurisdicional, face aos elementos que só ele está em condições de apreciar, chegar á conclusão ocasionada por esse naufrágio, especialmente se não tomou as medidas destinada a prevenir esse acontecimento, com as relativas á escolha do navio".

Isto significa que o afretador, v.g., embora insusceptível de ser accionado como tal - por não permitido ao abrigo da regra da canalização $0^{13}$ - fundamental no sistema CLC/ Fipol - já o pode ser enquanto "detentor anterior". Foi, justamente, tendo presente essa eventualidade e considerando o impedimento referido, lias aceite pelo tribunal - que este equacionou a eventual responsabilidade do produtor dos hidrocarbonetos - se encarados como resíduos - na produção dos danos causados.

Nesses casos [quando por efeito da aplicação da Convenção do Fipol, não for possível demandar o proprietário do navio ou afretador], o acórdão entende que o direito nacional deverá permitir que os ditos custos sejam suportados pelo produtor do produto gerador dos resíduos (le producteur du produit générateur des déchets) derramados. Sem embargo desta passagem não ser clara, julgo que um dos seus possíveis objectivos é o de permitir accionar o produtor e o afretador do navio afastando assim, de um modo inovador a lógica do princípio da canalização, própria das convenções marítima e, como tal central na CLC/92 (artigo III/4). De facto, a lógica dos resíduos é a única que está presente no acórdão do TJCE como mostra a expressão producteur du produit générateur des déchets, que carece de qualquer sentido fora do quadro jurídico dos resíduos terrestres em que o incidente do Erika foi situado no TJCE.

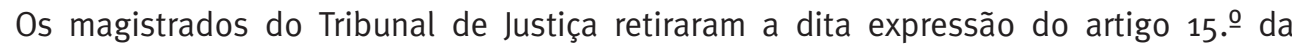
directiva 75/442/CEE que responsabiliza, “...o produtor do produto gerador dos resíduos”. Penso, contudo, o tribunal não levou até ás suas últimas consequências as premissas de

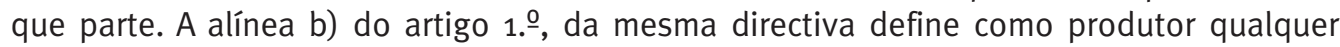
pessoa cuja actividade produza ou possa produzir resíduos (produtor inicial) e ou qualquer pessoa que efectue operações de pré-tratamento, de mistura ou outras que conduzam a uma alteração da natureza ou da composição desses resíduos. Esta redacção, não exclui a refinagem de ramas de petróleo. De facto, esta actividade pode compreender a produção de resíduos ou operações de pré-tratamento de mistura ou outras que conduzam a uma alteração da natureza ou da composição desses resíduos. Neste caso - sobretudo na pura lógica do aresto - isso releva em termos de obrigação indemnizatória do produtor do produto, se a refinagem - ou actividades conexas - tiverem contribuído para o risco, ou seu agravamento, de aparecimento da poluição causada pelo naufrágio do navio [pollution occasionnée par le naufrage du navire]. Dizer que é através do direito nacional que deve ser assegurada a responsabilização do "produtor do produto gerador dos resíduos" não é contraditório com o facto do acórdão admitir que o direito comunitário deva, nos casos que indica, ceder perante as convenções internacionais e aceitar as exonerações legais nelas contidas. De facto, por um lado o direito, nomeadamente comunitário dos resíduos terrestres move-se numa esfera jurídica diversa da das convenções marítimas

${ }^{13}$ Cfr. infra, n. $\stackrel{0}{5}$, (i)

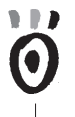




\section{$\operatorname{Rer} C E D$ ○̈UA

potencialmente aplicáveis (Marpol, CLC, Fipol, Fundo Complementar, HNS Convention etc.). Por outro lado, mais do que uma cedência, trata-se, sobretudo de uma relação de complementaridade e apenas nos casos em que a mesma se torna necessária em função da necessidade de assegurar a concretização do princípio da indemnização integral dos danos. Mesmo que só implicitamente, a opção do TJCE de encarar, a partir da normativa comunitária em matéria de resíduos, o sistema de Londres como uma realidade susceptível de não assegurar o ressarcimento integral do dano, afecta os casos em que as indemnizações sejam insuficientes. Sempre que isto suceda, caso da Commune de Masquer a soma compensatória deverá ser complementada. A rápida apresentação do aresto leva-nos à seguinte interrogação: qual o seu contributo para assegurar uma melhor e mais efectiva protecção dos bens ambientais? Posta assim a questão, direi que há duas facetas a ter em conta. Em primeiro lugar, a afirmação do princípio do poluidor-pagador como instância reguladora a ter em conta no plano normativo. Outrossim, a aceitação da possibilidade dos lesados optarem pelo título jurídico que entendam para acautelar os seus direitos, deste modo enfraquecendo a pura lógica da canalização.

4 - Mesmo que a expressão poluidor-pagador apareça no aresto de forma algo subalternizada a referência a esse princípio, só por si, merece ser assinalada. Na verdade, traduz a manifestação plena, no plano da poluição marinha por hidrocarbonetos, de preocupações que não sendo desconhecidas no sistema CLC/Fipol só se manifestavam nele de modo excessivamente discreto. 0 quadro em que o TJCE apela à regra em causa provem do facto do aresto configurar a eventualidade da soma concedida ao abrigo do sistema CLC-92/Fipol, pelos vários motivos que de modo hipotético admite, não assegurar o integral ressarcimento dos danos sofridos pelo lesado, situação que rejeita. Em pano de fundo dessa recusa afirma o direito a uma indemnização integral dos danos do lesado que resultem da poluição por só assim se obter a consagração prática da regra poluter-pays.

Neste enunciado de princípios o tribunal tinha diante o caso de um lesado, a Commune de Masquer, que embora ressarcida não o fora totalmente, justamente por falta de meios por parte do Fipol. Tendo a referida comunidade sofrido danos, “...correspondant à diverses dépenses de nettoyage du littoral consécutives au naufrage du navire ERIKA" ${ }^{14}$ (itálicos meus), não se antolha duvidoso de que estivessem presentes danos ambientais. A, apenas parcial, indemnização recebida levou pois à afirmação judicial da necessidade de ter presente o mencionado princípio cujo conteúdo não é precisado pelo TJCE. Ora, a verdade é que a expressão poluidor-pagador não é inequívoca. Não se vendo na decisão do TJCE qual o sentido que o tribunal lhe pretendia atribuir o intérprete terá de o reconstituir. Como ponto de partida dessa tarefa de reconstrução, admito a razoabilidade da ideia de que o TJCE tinha em vista uma noção jurídica ${ }^{15}$. Assim, tendo referido no aresto $^{16}$ entre a legislação aplicável a este tipo de questões - as convenções relativas à CLC-92 e ao Fipol, penso ser admissível admitir que deverá tratar-se de uma noção jurídica do princípio que seja harmonizável com as mesmas. Estas convenções internacionais têm como traços fundamentais consagrarem a responsabilidade por actividades perigosas por

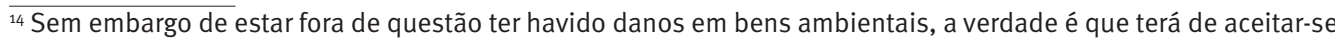
como algo vaga a expressão "nettoyage du littoral". Seria preferível dizer que bens do ambiente foram atingidos, designadamente, se costas, praias, fauna, flora, em suma elementos que integram o ambiente marinho.

${ }^{15}$ Afirmada pela primeira vez em sede de poluição transfronteiriça na arbitragem Trail Smelter de 1941, só muito mais tarde foi retomada pela OCDE; sobre esta arbitragem, cfr. KEVIN MADERS, Trail Smelter Arbitration, in: R. BERNHARDT ed.) Encyclopedia of Public International Law, Volume IV, (2000), p. 900; segundo MARIA ALEXANDRA DE SOUSA ARAGÃO, "...como o prova a sua história, o PPP tem as suas raízes ideológicas na Economia e não no Direito", $O$ princípio do Poluidor Pagador, Pedra Angular da Política Comunitária do Ambiente, Stvdia Ivridica 23, Universidade de Coimbra, Coimbra Editora, Coimbra 1997, pág. 61.

${ }^{16}$ Acórdão do TJCE citado, n.ำ s 3, 4 e 5, respectivamente.
} 
parte do proprietário do navio e, ao mesmo tempo, admitirem, por um lado, restrições ao número de lesantes susceptíveis de serem accionáveis em juízo e, por outro lado, conhecerem exclusões e exonerações aos danos pagos, salva a hipótese de negligência na sua produção. Creio que estas regras satisfazem os critérios jus-internacionais vigentes em sede de princípio poluidor-pagador. Na verdade, ocupando-se desta matéria, após referir as dúvidas que, num plano mais geral este princípio suscita, Rüdiger Wolfrum, observa que "Actualmente a principal tendência da prática internacional [no que respeita o princípio poluidor-pagador] aponta na direcção da responsabilidade objectiva, isto é a responsabilidade baseada na existência do dano mas permitindo exonerações ou limitações de responsabilidade" ${ }^{17},{ }^{18}$. Pelas razões expostas aceitaremos essa ideia-força no preenchimento do conteúdo normativo do dito princípio. Em todo o caso, sempre se poderá inquirir se seria essa a via que o TJCE seguiria. Na verdade, o acórdão Commune de Masquer está impregnado da concepção de acordo com a qual o referido princípio poluidor-pagador assenta na reparação integral do dano.

Isto encerra o intérprete na seguinte alternativa. Ou aceita os critérios das mencionadas convenções internacionais, afastando então a reparação integral do dano ou opta por esta última solução. Mas, sendo assim, então o princípio em causa não pode arrimar-se às ditas convenções internacionais. Na opção por uma das duas alternativas possíveis, embora com alguma hesitação, seguiria a segunda, única maneira de assegurar o princípio cardinal do direito civil, da reparação integral do dano. De facto, a ser assim, então o acórdão do TJCE seria desnecessário pois o sistema de Londres, em boa medida, corresponde às exigências de Rüdiger Wolfrum. Quanto a uma eventual objecção de que, a ser deste modo, não se teriam em conta as convenções integradoras do dito sistema CLC/Fipol a verdade é que a solução decorre da jurisprudência comunitária não se vendo que o Fipol a ele se tenha oposto. Uma outra ordem de considerações concorre, porém, para reforçar a opção que acima propusemos. Na verdade, observou-se já, a respeito das convenções internacionais que estabelecem regimes de responsabilidade civil, que as mesmas revelam no ethos do actual direito internacional, incluindo o ambiental, preocupações e facetas em que "... questões de lealdade (fairness) se tornaram centrais" ${ }^{19}$. Por isso não se vê que a aplicação das directivas comunitárias em sede de resíduos complementadas com as convenções que compõem o sistema CLC/Fipol, pois na realidade é disso que se trata, possa representar qualquer violação das mesmas. Seja como for o telos último dessas convenções - procurar repartir os riscos presentes no transporte marítimo de hidrocarbonetos pelos vários intervenientes no transporte - mantém-se.

\footnotetext{
${ }_{17}$ RÜDIGER WOLFRUM, Means of Ensuring Compliance with and Enforcement of International Environment Law, Recueil des Cours, [1998], Vol. 272, pág. 89.

${ }^{18}$ É esta a solução acolhida no artigo 7. ${ }^{\circ}$ do decreto-lei n. ${ }^{\circ}$ 147/2000, de 29 de Julho, cujo objectivo confessado foi o de consagrar no direito português o princípio poluidor-pagador. Em todo o caso, situando embora a referida regra no campo da responsabilidade civil, entende que a mesma tanto pode dar lugar à responsabilidade objectiva (artigo 7. ${ }^{\circ}$ ) como à responsabilidade civil subjectiva (artigo 8.ํ). Bem vistas as coisas, não me parece que este diploma introduza algo de novo, a este respeito, no direito privado português, nomeadamente considerando a disciplina do CC. De facto, o regime da responsabilidade civil objectiva (aí denominado, porventura com mais propriedade, já consentia a prova da culpa do lesado. É verdade que poderia, talvez, levar a sustentar que a responsabilidade civil pelo risco no CC tem natureza excepcional o que poderia justificar que, a este respeito, se pudesse falar num regime insusceptível de aplicação a situações que não fossem as descritas no código. A redacção da 1. ${ }^{a}$ parte do artigo 8.으 evoca fortemente 0 artigo $483 .{ }^{\circ}$ do Código Civil. Mas, ainda que assim fosse, a verdade que, como na doutrina já se advertiu, o art. $.493 / 2$ pode “....suprir de certa forma a inelutável desactualização do sistema...” (JOSÉ CARLOS BRANDÃO PROENÇA, A conduta do lesado como pressuposto e critério de imputação do dano extra contratual, Coimbra, Almedina, 1997, pág. 240). Decisiva, porém, será a leitura jurisprudencial, em especial a dos artigos 7.ำ 9.․․ ${ }^{19}$ THOMAS M. FRANK, Fairness in the International Legal and Institutional System, General Course of Public International Law, Recueil des Cours, [1993], Vol. 240, págs. 356 e segts.
} 


\section{RerCED光UA

5 - A outra contribuição do presente aresto do TJCE em sede de direito ambiental, dissese acima, é a irrestrita aceitação da possibilidade dos lesados optarem pelo título jurídico que entendam para a tutela dos seus direitos. 0 relevo desta permissão assenta no facto de, assim, ser mais fácil aos lesados obterem o ressarcimento integral dos danos sofridos. O que está em jogo no alargamento da legitimidade passiva neste sector normativo é a decidida recusa do princípio da canalização. Tão gravoso pode o mesmo ser que, mesmo no sistema CLC/Fipol, não foi levado até às suas últimas e lógicas consequências. A exposição da temática agora objecto da nossa atenção em causa será feita em dois momentos. Em primeiro lugar exporemos em que consiste e o que justifica a regra da canalização (i). Em segundo lugar mostraremos que, embora de forma restrita, nada impede que outros sejam civilmente responsáveis mesmo perante a regra da canalização, que não é pois, princípio absoluto (ii) e, enfim iii), veremos qual o estado da questão após o aresto de TJCE (iii).

(i) Ao falar-se na regra da canalização tem-se presente o facto dos preceitos do sistema CLC/Fipol relevantes em matéria de responsabilidade civil determinarem, como que apenas o proprietário do navio ${ }^{20}$, com exclusão de qualquer outra eventual entidade, possa ser responsabilizado Segundo dispõe o artigo III/1 da $\mathrm{CLC} / 92$, «O proprietário de um navio no momento em que se verifique um evento (...) é responsável por qualquer prejuízo devido à poluição...». Esta regra, em seguida, é precisada no subsequente artigo III/4, que considera ser o proprietário do navio destinatário forçado da responsabilidade civil, pelos danos causados pela poluição ocorrida ${ }^{21}$. Na verdade, na CLC a individualização do obrigado a ressarcir os danos causados ao lesado nada tem a ver, necessariamente, com o apuramento de qual o autor material da conduta lesiva. Essa individualização, em princípio e num momento inicial, concentra-se tão só, na tarefa, eminentemente jurídica, de determinar quem tem a qualidade de proprietário do navio poluidor decorrendo dessa individualização o apuramento de quem é civilmente responsável pelos danos. Assim, outros intervenientes, também potencialmente, à partida responsáveis, são, liminarmente isentos de qualquer possibilidade de responsabilização. É nesta realidade que consiste a regra da canalização ou seja o princípio da «imputação da obrigação de ressarcir os lesados apenas aos sujeitos indicados pelo legislador $\aleph^{22}$. A explicação da adopção deste mecanismo jurídico caracterizador da CLC - que não deixa de seduzir pela sua elegância formal ${ }^{23}$ encontra-se na própria génese do sistema CLC/Fipol. Este privilegiou o proprietário enquanto

\footnotetext{
$\overline{{ }^{20}} \mathrm{O}$ sentido da expressão legal, proprietário do navio não é isenta de dúvidas. Literalmente a mesma exclui o armador, no que toca ao destinatário desta forçada responsabilização. Contudo, o artigo 3/I da CLC - seja no texto de 1969 seja no de 1992 - refere o proprietário do navio. A versão oficial portuguesa de 1969 acompanha «da versão francesa que utiliza o termo propriétaire. Ao traduzir-se o texto de 1992, continuou a utilizar-se a palavra proprietário. Mas enquanto a versão portuguesa de 1969 estava acompanhada da versão francesa a versão de 1992 está acompanhado pela redacção inglesa. Ora, o emprego da expressão inglesa leva a que o intérprete possa admitir estarem aqui incluídas outras realidades. Com efeito, o termo owner, já se assinalou, «...em direito marítimo inglês pode assumir uma variedade de significados e de implicações...”, Assim, v.g., MICHELE COMENALE PINTO, La responsabilita per inquinamenti da idrocarburi nel sistema della CLC, Cedam, Pádua, pág. 62.

${ }^{21}$ A versão portuguesa está longe de ser claro e, mais grave, não acompanha as versões oficiais inglesa ou francesa. 0 texto português preceitua que, «Nenhum pedido de reparação por prejuízos devidos à poluição, que não tenha por fundamento o disposto na presente Convenção, pode ser formulado contra o proprietário». O que precede é de difícil inteligibilidade. Na verdade, o que se dispõe na passagem transcrita é que «Nenhum pedido de reparação por prejuízos devidos à poluição pode ser formulado contra o proprietário a não ser ao abrigo desta Convenção. 0 texto inglês, na verdade, mostra ser assim ao prescrever «No claim for compensation for pollution damage may be made against the owner otherwise than in accordance with this convention». Igualmente, o texto da versão francesa, por seu lado, só consente uma tal leitura.

${ }_{22}$ MICHELE COMENALE PINTO, La responsabilita per inquinamento da idrocarburi nel sistema della C.L.C. 1969, Pádua, 1993, pág. 36.

${ }^{23}$ Neste sentido LAURENT LUCCHINI, afirma : «Le montage réalisé par les textes de 1969 e 1971 ne manque pas de séduction», Le Procès de L'Amoco Cadiz: Présente et Voies du Futur, Annuaire Français de Droit International, CNRS, Paris, 1985, pág. 765.
} 
responsável, em função de considerações ligadas à intenção de evitar conflitualidade e de facilitar a prova quer dos danos quer do respectivo responsável. Sabendo que nestes sinistros os danos são muito elevados considerou irrealista pretender que agentes como, v.g., membros da equipagem do navio, designadamente o seu comandante, os possam ressarcir, mesmo que tão só parcialmente. Assim, ao concentrar a responsabilidade civil sobre o proprietário, o legislador convencional teve em atenção considerações «...de predictability, de modo a realizar a insurability do contrato ${ }^{24}$. Isto, porventura, pode significar que imperativos de cariz jurídico-funcional, designadamente os que se conexionam com a temática seguradora, foram tidas em consideração, mesmo sacrificando imperativos normativos ${ }^{25}$. Mas, possa embora traduzir esse sentimento, não tem contudo em conta toda complexidade do problema.

(ii) Sem embargo do sistema CLC/Fipol assentar na ideia de canalização e verdade é que de modo algum nega a possibilidade de existirem outros responsáveis cíveis, ao prever a responsabilidade de terceiros. Ora, o dito produtor do produto gerador dos resíduos, pode ser responsabilizado na qualidade de co-autor do evento causador do evento poluidor, ao abrigo da $\mathrm{CLC} / 92$, embora sempre na base do pressuposto de que, por qualquer modo, teve intervenção no sinistro. Vejamos de que maneira. O artigo III da CLC/92 considera, (responsabilidade presumida por actividades perigosas ${ }^{26}$ ) que em caso de incidente por poluição o proprietário do navio é o responsável. Compreende-se a regra. $\mathrm{Na}$ verdade, invariavelmente a responsabilização provém da circunstância de, quem tem a possibilidade de administrar o navio antes do início da viagem, possui igualmente os meios para tal necessários e, portanto, igualmente, a obrigação de em momento prévio ao começo da expedição marítima, apurar tudo o que tem a ver com a navegabilidade do Tanquer. Mas não obstante ser assim, logo a seguir o $\mathrm{n} . \stackrel{0}{2}$ do artigo V da CLC-92, permite ao proprietário no petroleiro limitar a sua responsabilidade “...se provar que o prejuízo devido á poluição resultou de acção ou omissão que lhe seja imputada, cometida com a intenção de causar tal prejuízo ou com imprudência e o conhecimento de que tal prejuízo se poderia vir a verificar" (itálicos nossos).

Além disso, o sistema de Londres prevê a responsabilidade de terceiros, ao dispor na alínea b) do artigo III que cessa tal responsabilidade do proprietário se for feita a prova de que o prejuízo por poluição, "Resulta na totalidade do facto de um terceiro ter deliberadamente actuado ou omitido actuar com a intenção de causar um dano". Ora, nada impede - tudo, obviamente dependendo do modo como os acontecimentos se desenrolaram - que o afretador ou o produtor do produto gerador dos resíduos possam ter contribuído para o evento poluidor. Nestas hipóteses, a que acresce a de poder tratarse do transporte de ramas em bruto, se repete-se, a entidade que as extraiu ou que procedeu à sua refinagem - o produtor de produto - pode ser tida como responsável ao abrigo da CLC/92, porventura tenha a sua intervenção tenha sido relevante ou, tendo tido a possibilidade de evitar o incidente, ter omitido, por negligência grosseira (wilful

\footnotetext{
${ }_{24}^{24}$ LUIGI FERRARI BRAVI, Les Rapports entre Contrats et Obligations Délictuelles en Droit International Privé, Recueil des Cours, Vol. 146, pág. 377.

${ }^{25}$ Notam RENÉ RODIĖRE/MARTINE RÉMOND-GOUILLOUD: «Ninguém sabe aqui quem deve segurar-se: é preciso pedir ao fabricante de aerossóis para segurar-se contra poluição dos mares porque uma das suas garrafas arrisca-se um dia a explodir na ponte de um petroleiro provocando uma maré negra? É evidente, face ao super risco de catástrofe e à enorme carga financeira que representa, dever a responsabilidade ser canalizada para um dado meio capaz de premunir-se contra ele, La Mer, Droits de L'Homme ou Proie des États, Paris, 1980, pág 117.

${ }^{26}$ Neste sentido, cfr, o meu Poluição Marítima por Hidrocarbonetos e Responsabilidade Civil, cit., págs., 99 e segts., passim; cfr., ainda, MANUEL JANUÁRIO DA COSTA GOMES, Limitação da Responsabilidade por Créditos Marítimos, Almedina, Coimbra, 2010, págs. 373 e segts.
} 
misconduct ${ }^{27}$, a supressão dos factores que pudessem pôr em causa a navegabilidade e, desse modo, a segurança tanto do navio-tanque como da carga transportada. Estas preocupações impõem-se tanto mais quanto a responsabilidade do proprietário do navio pode ser total, privando-o mesmo do direito de constituir um fundo de limitação.

Assim será, se, art.ํ V/2 da CLC-92, “...se provar que o prejuízo devido á poluição resultou de acção ou omissão que lhe seja imputada, cometida com a intenção de causar tal prejuízo ou com imprudência e o conhecimento de que tal prejuízo se poderia vir a verificar" (itálicos nossos). Creio que a interpretação exigente e rigorosa deste preceito poderia ser passo importante para assegurar o ressarcimento dos danos reclamados, sem para isso haver a necessidade de complementar o sistema de Bruxelas. Na verdade, a concretização dos deveres que esta passagem do preceito impõe a qualquer responsável extremo cuidado na condução marítima e comercial do navio de que se tratar. De facto, a não se verificar um comportamento estritamente conforme com os padrões legais, tal actuação é sancionável, desencadeando a responsabilidade civil não só do proprietário do navio-tanque mas também dos que, por acção ou omissão contribuíram para o sinistro. Rigorosamente pois, a regra da canalização não deixava o sistema da CLC/Fipol completamente desprovido de meios para fazer face a sinistros caracterizados por elevados danos.

(iii) De qualquer maneira não foi esse o caminho seguido pelos litigantes que preferiram recorrer ao seu próprio direito nacional e ao direito comunitário em matéria de resíduos. Assim, nas suas respostas, o TJCE, acabou por ficar condicionado pelas questões prejudiciais postas pela CCass. A verdade é que esse facto acabou por determinar um importante apport ao problema do ressarcimento dos danos por poluição, ao abrigo do sistema de Londres, verdadeiramente a gata borralheira do direito ambiental

Com efeito, desde o início da sua vigência, paira sobre esse sistema compensatório a recorrente censura da insuficiência dos meios disponibilizados para indemnizar os lesados $^{28}$. Não é alheia a tal facto, a herança da convenção de Bruxelas de 1957 sobre a responsabilidade dos proprietários de navios de alto mar, único meio de lidar com este tipo de situações à data da tragédia ambiental causado pelo Torrey Canyon ${ }^{29}$ sinistro que, de resto, se encontra na génese da CLC. Essa influência terá, porventura, imprimido tinha uma indisfarçável inspiração jus-maritimista, pensando muito nos danos marítimos e pouco nos ambientais. A isso acrescia a preocupação de respeitar os princípios da responsabilidade civil por culpa a que a tradição jus-maritimista tão fortemente está ligada. Nesse debate os imperativos de protecção do meio ambiente não eram a primeira das preocupações. Aliás, a realidade ecológica era preocupação de que mal se falava na, hoje longínqua, Conferência de Bruxelas de 1969. De facto essa temática só viria a fazer a sua entrada no sistema ressarcitório CLC/Fipol e, mesmo assim, recorde-se, algo discretamente em $1992^{30}$. Ora, à medida que a gravidade dos sinistros aumentava e, concomitantemente, o número de lesados e a expressão quantitativa dos danos, os desequilíbrios dos mecanismos instituídos aumentavam e, bem assim as críticas de que o sistema era objecto.

Para fazer face a esta dificuldade, tendo a sua tarefa judicativa sido balizada por marcos que a situaram fora do âmbito da CLC/Fipol, os juízes do Luxemburgo às entidades que o sistema CLC/Fipol já responsabilizava - o proprietário do navio - acrescentaram ainda

\footnotetext{
${ }_{27}$ Sobre wilful misconduct cfr. PAULA IVALDI, wilful misconduct e colpa grave, Tra Diritto Internazionale e Diritto Interno, Rivista di Diritto Internazionale Privato e processuale, Ano XXII [1986], págs. 327 e segts., passim, no qual perpassam ensinamentos doutrinários de sinal equivalentes - senão mesmo iguais - aos constantes da jurisprudência recordada na nota anterior.

${ }^{28}$ Assim, v.g. LAURENT LUCCHINI, Le Procès de L’Amoco Cadiz, cit. pág. 767.

${ }^{29}$ Sobre este caso, cfr. ROBERT H. STANSFIELD, Torrey Canyon The, in: R. BERNHARDT ed.) Encyclopedia of Public International Law, Volume IV, (2000), p. 867.

${ }^{30} \mathrm{Cfr}, 2 .^{\text {a }}$ parte da alínea b) do artigo" 6. da CLC/92.
} 
o produtor do resíduo e o afretador do navio. Para realizar tal desiderato, mantendo as premissas desse sistema, recorreram à lógica dos resíduos que, ao escapar à regra da canalização, permite accionar tais entidades. Mesmo assim, o TJCE, mantendo-se fiel ao respeito do direito internacional público, notou que tais entidades - eventualmente também civilmente responsáveis - apenas em via subsidiária poderiam ser demandadas. Isto poderá suceder, como afirma (n. .82 do aresto) imediatamente antes da alusão que faz ao princípio a que acima aludimos do poluidor-pagador "...caso se verifique que os custos associados à eliminação dos resíduos gerados pelo derrame acidental de hidrocarbonetos no mar não são assumidos pelo FIPOL ou não o podem ser (...) o direito nacional de um Estado-membro, incluindo o direito resultante das convenções internacionais, obsta a que esses custos sejam suportados pelo proprietário do navio e/ou pelo seu afretador (...) esse direito nacional deverá então permitir (...) que os referidos custos sejam suportados pelo produtor do produto gerador dos resíduos assim derramados".

Esta resposta suscita, em todo o caso, a questão de saber se seria possível que uma indemnização recebida ao abrigo de dado sistema de ressarcimento de danos - o sistema CLC/92-Fipol - fosse complementada por um outro sistema indemnizatório, aqui o sistema comunitário de resíduos, suscitando-se aqui a questão da possibilidade de aquisição de uma prestação ao abrigo de mais de um título jurídico ${ }^{31}$. A questão tem tanta maior razão de ser quanto o sistema indemnizatório CLC/Fipol também prevê o ressarcimento de danos causados por resíduos em cuja composição entrem hidrocarbonetos ${ }^{32}$. Assim, bem vistas as coisas, esse sistema ressarcitório também já incluía à data do sinistro, no seu âmbito normativo a possibilidade de proceder ao ressarcimento dos danos causados por resíduos em cuja composição entram hidrocarbonetos. Consequentemente, um eventual pedido de indemnização por prejuízos causados por resíduos também era ressarcível ao abrigo do quadro normativo do sistema CLC/Fipol que, na verdade, também a admitia sem qualquer tipo de dificuldades. No plano jurídico, não era pois necessário recorrer à disciplina comunitária - sem embargo da sua maior clareza - para obter a compensação desses danos.

Quanto à questão colocada, adianto desde já que, não desconhecendo embora a dificuldade da resposta, que essa possibilidade - perfilhada neste aresto do TJCE e já aceite pela jurisprudência francesa ${ }^{33}$ - não é inconciliável com o sistema CLC/Fipol. Foi esse, v.g., o ponto de vista da Cour d’Appel de Rennes. Com efeito, após afirmar não ser o Fipol “... um fundo que exprime a limitação da responsabilidade do armador, como o previsto pela convenção de 1969, mas um mecanismo colectivo de financiamento destinado a cobrir um risco...”, considerou que "...a constituição do FIPOL (ou do [Fundo] constituído eventualmente pelo armador, do qual no caso concreto nada se sabe) não impede as vítimas de procurar a responsabilidade dos poluidores com base no direito comum e que, por isso é possível a acção da "Commune de MESQUER" contra as sociedades TOTAL com esse fundamento". De facto, a eventualidade invocada por estas últimas, segundo a qual a indemnização por parte do Fipol, se fosse demandado, e, de um modo geral, dos organismos criados para esse fim,

\footnotetext{
${ }^{31}$ Assim, E. ROUCOUNA, Engagements parallèles et contradictoires, Recueil des Cours, vol. 206, págs. 9 e segts., passim. ${ }^{32} \mathrm{CLC} / 92$, artigo $1 / 5$.

${ }_{33}$ Foi esse, v.g. o ponto de vista da Cour d’Appel de Rennes. Com efeito, após ter afirmado que o FIPOL não é “... um fundo que exprime a limitação da responsabilidade do armador, como o previsto pela convenção de 1969, mas de um mecanismo colectivo de financiamento destinado a cobrir um risco...", considerou que o FIPOL, (ou o constituído eventualmente pelo armador, do qual no caso concreto nada se sabe) não impede as vitimes de procurar a responsabilidade dos poluidores com base no direito comum e que, por isso a acção da "Commune de MESQUER" contra as sociedades TOTAL com esse fundamento é possível, pois a eventualidade invocada por estas últimas, que a indemnização do FIPOL, se fosse demandado, e, de um modo geral, dos organismos criados para esse fim, poderia ressarcir as vitimas da totalidade dos seus direitos, é inoperante a este respeito".
} 


\section{$\operatorname{Rer} C E D$ ○̈UA

poderia ressarcir as vítimas da totalidade dos seus direitos, é inoperante a este respeito ${ }^{34,35}$. A ser assim, nada impede os lesados, uma vez esgotadas as quantias pertencentes ao Fundo referido no artigo $\mathrm{V}$ da $\mathrm{CLC} / 92$ e, bem assim, as do Fipol, de recorrer a outras entidades, nomeadamente as referidas pelo TJCE. Considero pois oportuna a concessão da faculdade do lesado escolher o título jurídico ao abrigo do qual pretende ser indemnizado. Creio, de resto, o reconhecimento dessa possibilidade de escolha - mesmo que nos moldes apertados do acórdão - constitui - um dos mais importante apports do aresto do TJCE em sede de tutela do ambiente marinho considerando as muitas críticas de que é alvo o sistema CLC/ Fipol. A verdade é que não pode dizer-se que o aresto do TJCE, tenha desrespeitado - ou não tido em consideração - o sistema de indemnização de danos resultante da CLC/92, complementada ou não pela Convenção do Fipol.

Na verdade, constatando que o Fipol nem sempre assegura a compensação integral dos danos - lógica da limitação da responsabilidade civil das convenções marítimas - sugeriu uma alternativa ao mesmo quando ocorresse uma situação de não ressarcimento integral. Alternativa, acresce, que respeita o sistema CLC/Fipol. Com a doutrina perfilhada neste acórdão o peso da indemnização em caso de dano ambiental, tenderá a centrar-se não apenas no momento marítimo - o derramamento no mar dos hidrocarbonetos - mas, também nos momentos terrestres - a posse, detenção e refinagem de hidrocarbonetos. Nem por isso desaparece a consciência da necessidade de dividir a obrigação de ressarcir o lesado entre carregadores e transportadores. Aliás, não se vê porque não seria assim tão só por se poder, às entidades civilmente responsáveis segundo o sistema ressarcitório CLC/Fipol, eventualmente, fazer acrescer outros responsáveis. Assim, a presença da lógica de resíduos - mesmo sem esquecer que a mesma não foi esquecida no sistema CLC/Fipol - ao aceitar a responsabilização de outras entidades, permite complementar nos casos em que isso se mostrar necessário, o montante das indemnizações concedidas numa lógica de poluição. Isto, é fácil de ver, em nada põe em causa a aplicabilidade do sistema ressarcitório CLC/Fipol que, mais do que substituído é, deste modo, complementado. No contexto descrito, compreendese que a solução do TJCE não tenha suscitado ao Fipol quaisquer especiais reacções.

Justifica-se ainda uma última palavra. Já mais acima nos referimos ao papel da ideia de fairness no âmbito jus-ambiental. Acrescentaremos agora que essa mesma ideia de fairness neste campo pode levar a que o Estado seja “...residualmente responsável se o operador privado não indemnizar" ${ }^{36}$. Encontraremos neste juízo mais um motivo para considerar que a aplicação das convenções que compõem o sistema CLC/Fipol em conjunto com as directivas comunitárias em sede de resíduos - pois, na verdade, é disso que se trata - não traduz qualquer violação desse sistema. Importante será que o telos último dessas convenções, como aliás, de todas as convenções marítimas em matéria de poluição marinha possa fazer repercutir os riscos do transporte marítimo de hidrocarbonetos pelos intervenientes no mesmo, nomeadamente, os responsáveis pelas actividades, respectivamente, de exploração e refinagem e de shipping petrolífero. Creio que essa repartição se mantém.

Carlos Oliveira Coelho Advogado

\footnotetext{
34 Cour d’Appel de Rennes, ac. cit.

${ }_{35}$ A doutrina francesa, embora raciocinando a partir da versão de 1969 da CLC, considera que o princípio da canalização é passível de ser contornado; neste sentido LAURENT LUCCHINI, Le Procès de L’Amoco Cadiz, cit., pág. 770. A questão foi objecto de longa atenção na decisão “in the Matter of Oil Spill By the Amoco Cadiz Off the Coast of France on March 16, 1978., 954 F.2d 1279 (7th Cir. 1992), Federal Circuits, 7th Cir.) que, igualmente, veio a concluir por tal possibilidade (cfr. parte VII, D da decisão).

${ }^{36}$ THOMAS M. FRANK, Fairness in the International Legal and Institutional System, cit., pág. 357.
} 